تغييرات زمانى و مكانى ردياى اكولوزيكى آب و تجارت آب مجازى در محصول بادام فارياب و ديم در ايران

كامبيز وفايى'، امالبنين بذر افشان '”* و هادى رمضانى اعتدالى '

(تاريخ دريافت: (|r/4/

جكيده

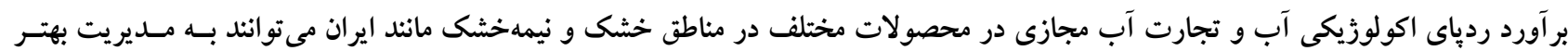

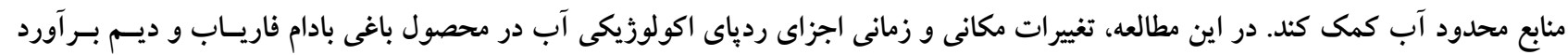

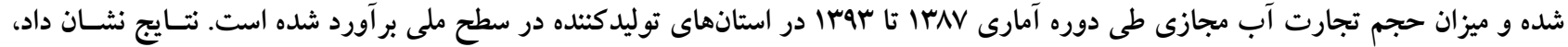

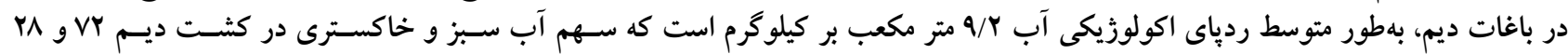

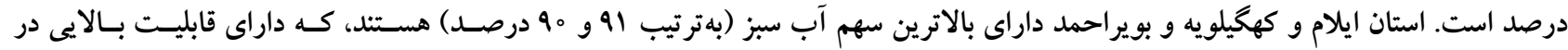

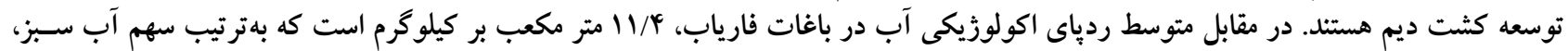

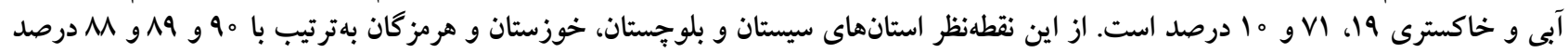

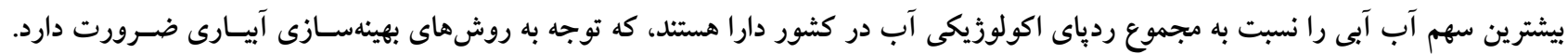

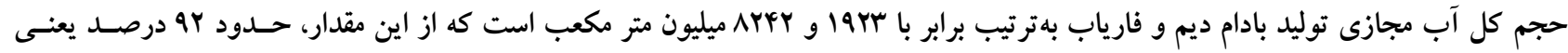

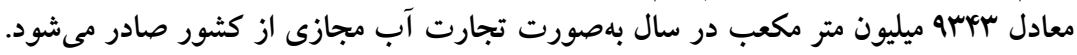

وازههاى كليدى: ردياى آب، بادام ديم و فارياب، مقياس استانى، مقياس ملى

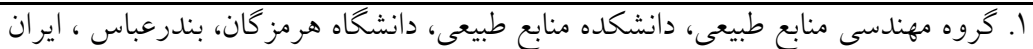

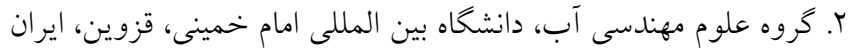

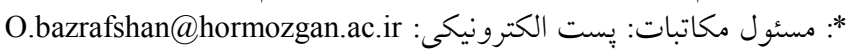


ذخيره منابع آب سطحى و زيرزمينى در سطح ملى مسى شـود

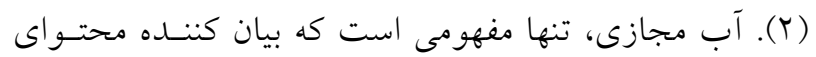

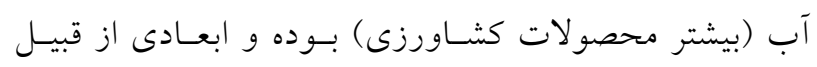

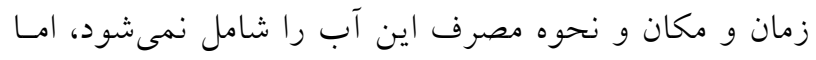

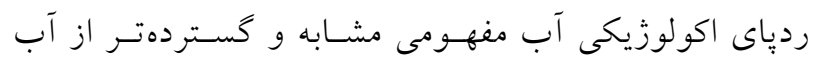

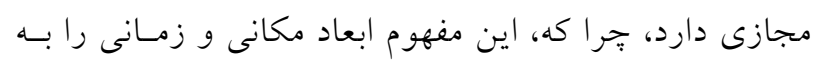

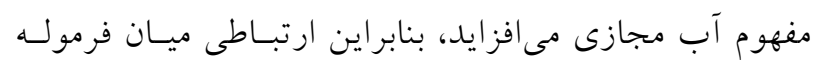

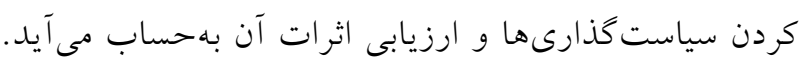

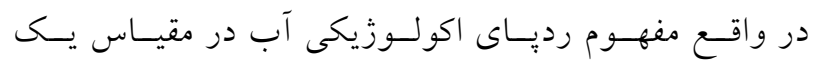

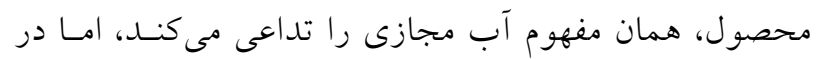

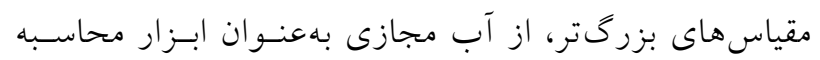

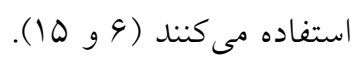

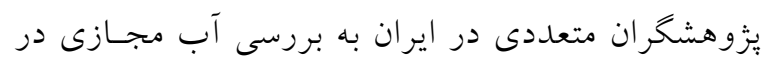

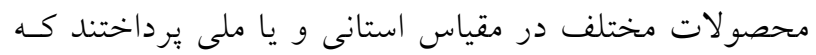

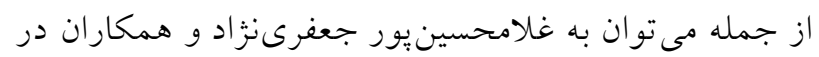

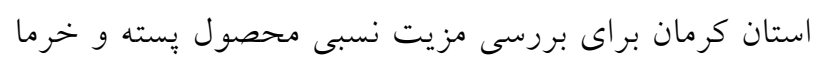

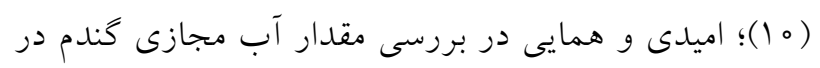

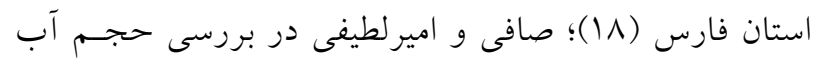

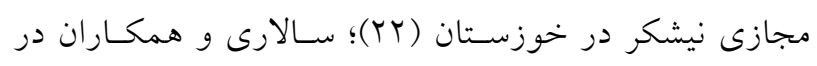
تحليل زمانى و مكانى تغييرات آب مجازى گنسـدم در استـان

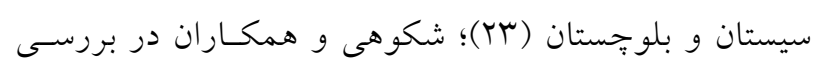

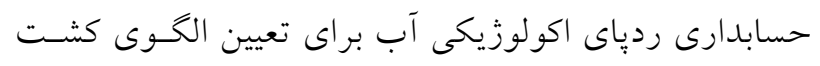

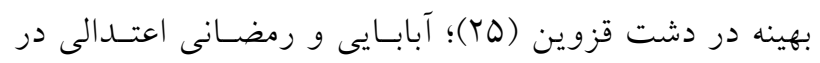

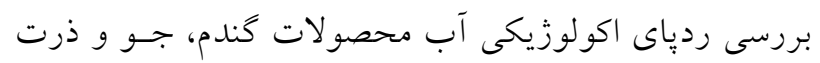

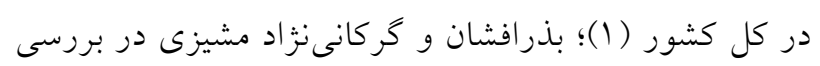

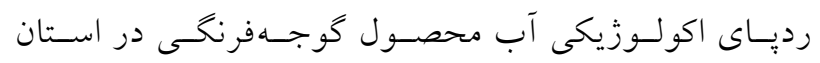

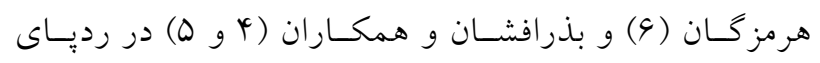

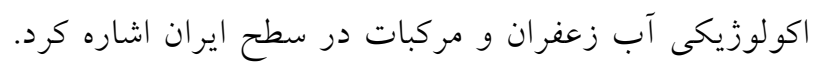

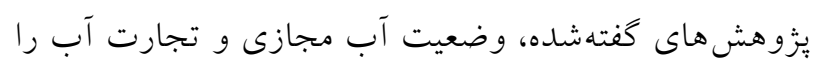

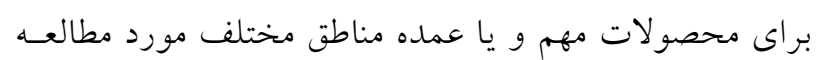

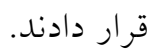

لذا در يك جمع بندى مى توان كفت، مرور يزوهش ها نشـان

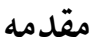

ايران يكى از عمدهترين كشورهاى توليد كنتــه و صـادر كنــده

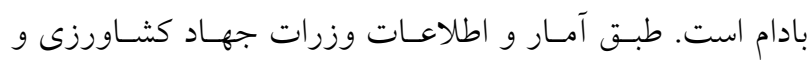

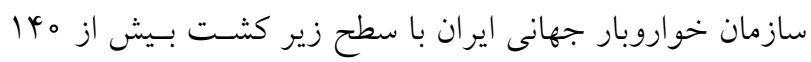

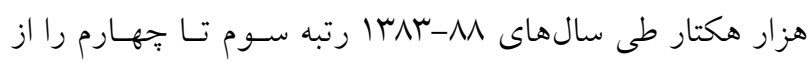

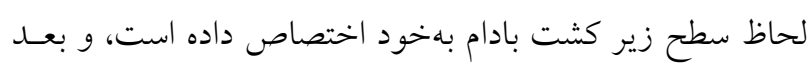

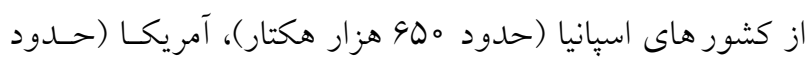

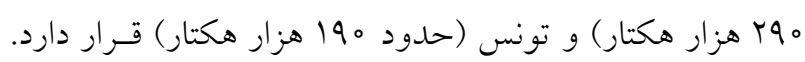

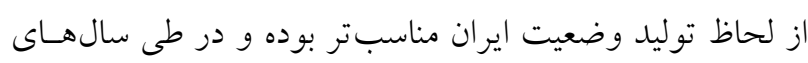

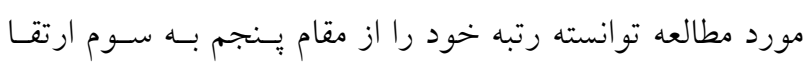

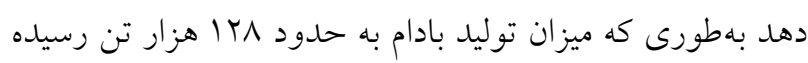
و در بخش صادرات توانسته اسـت جـزء ده كشـور اول صـادر

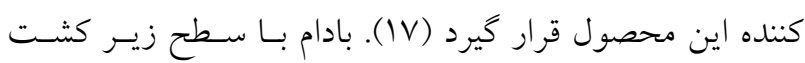

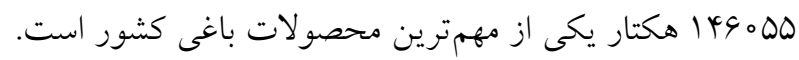

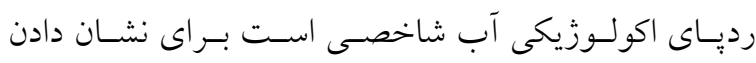

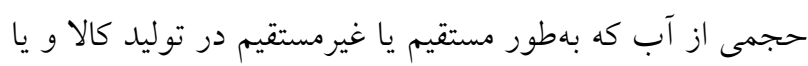

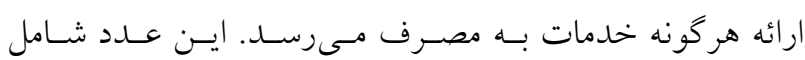

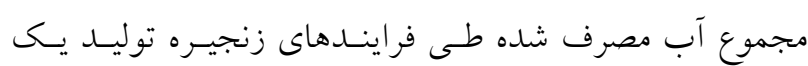
محصول خواهد بود (Y) (Y).

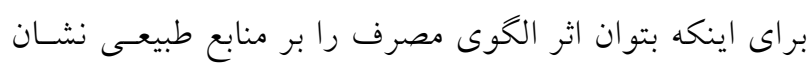

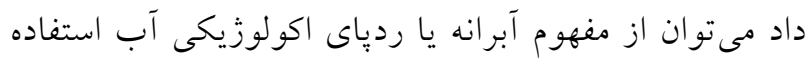

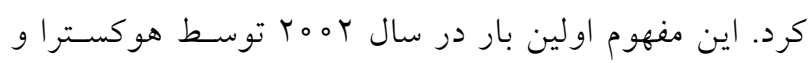

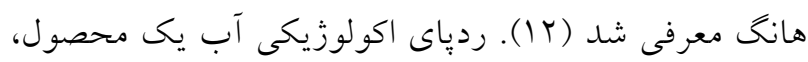

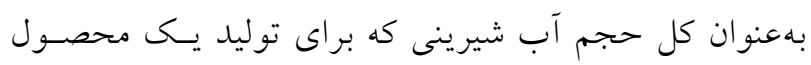

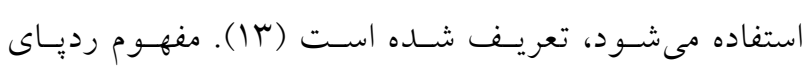

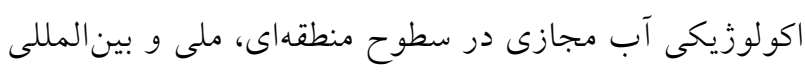

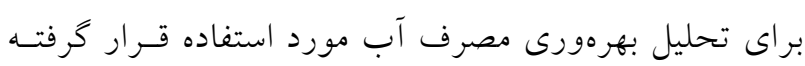

انتقال آب مجازى يكى از مكانيزمهاى ذخيرهسـازى منـابع

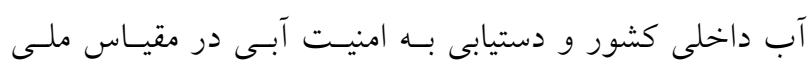

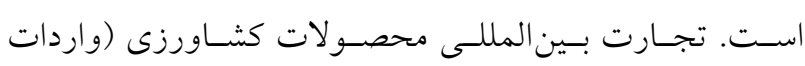

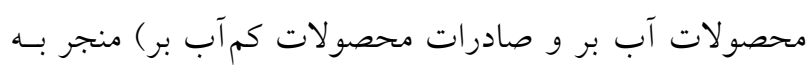


در اين مطالعه، ردياى اكولـوزيكى آب سـبز، آبسى و خاكسترى در

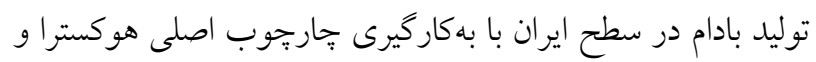

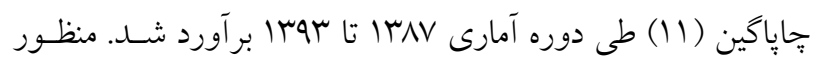

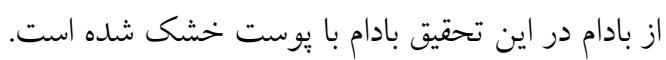

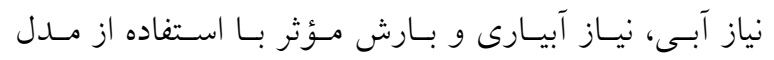

CropWat محاسبه شـــ ميـزان تبخيـر و تعـرق كيـاهى و نيـاز

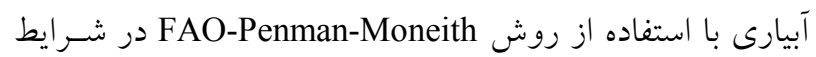

استاندارد و غير استاندارد محاسبه شد (؟):

$\mathrm{WF}_{\mathrm{Green}}=\frac{\left(\mathrm{P}_{\mathrm{e}}\right) * 10}{\mathrm{Y}}$

$\mathrm{WF}_{\text {Blue }}=\frac{\left(\mathrm{ET}_{\mathrm{c}}-\mathrm{P}_{\mathrm{e}}\right) * 10}{\mathrm{Y}}$

$\mathrm{WF}_{\text {Gray }}=\frac{\alpha * \mathrm{NAR}}{\mathrm{C}_{\mathrm{Max}}-\mathrm{C}_{\mathrm{Nat}}} * \frac{1}{\mathrm{Y}}$

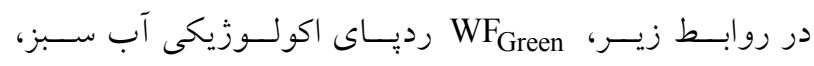

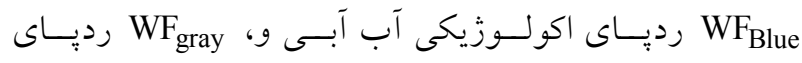

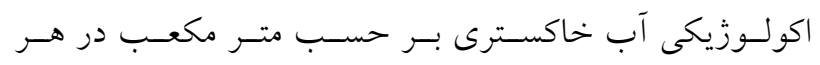

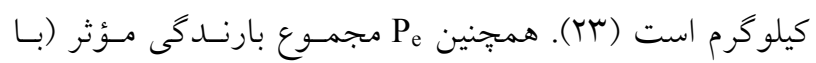

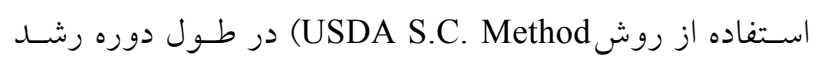

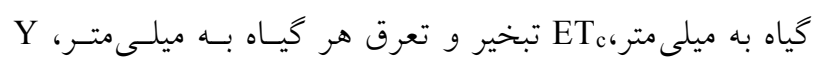
عملكرد هر محصول به تن در هكتار، م درصد تلفات كودهاى

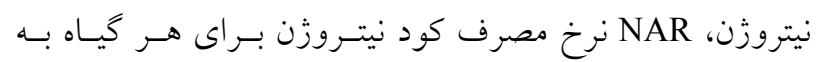

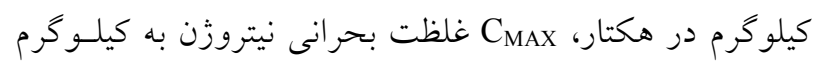

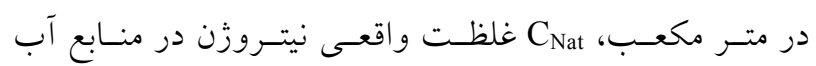

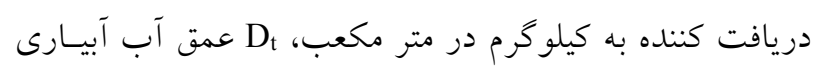

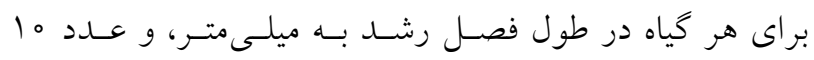

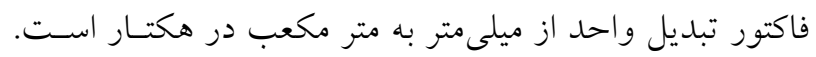

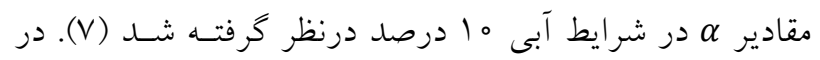

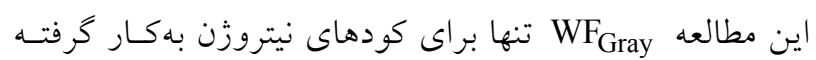

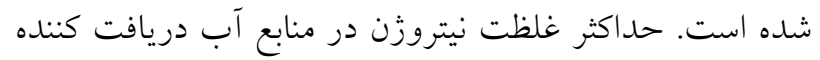

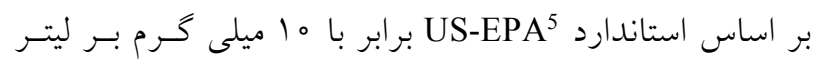

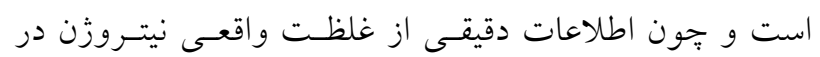

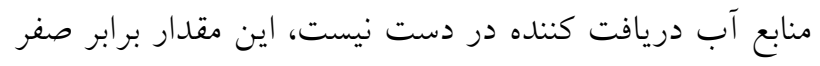
درنظر كرفته شد (V) (vن)
مى دهد، تخمسينهـايى از رديـاى اكولـوزيكى آب در مقيـاس

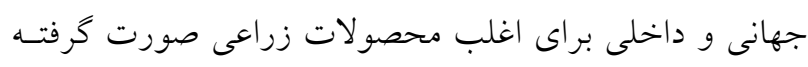

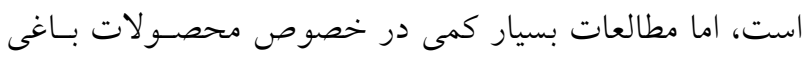

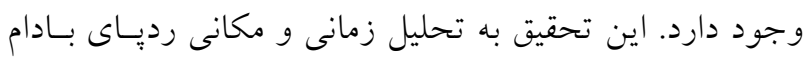

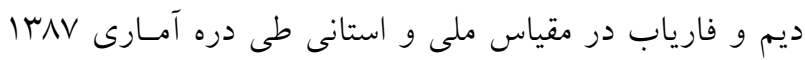

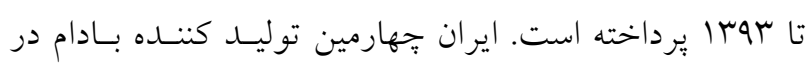
دنياست كه بخش عمدهاى از توليدات ملى را به ساير كشورها

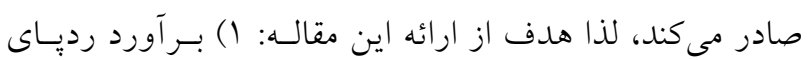

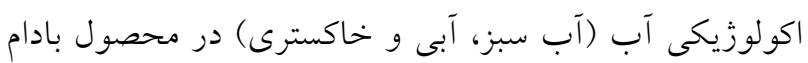

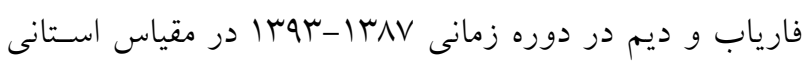

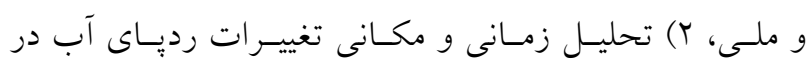

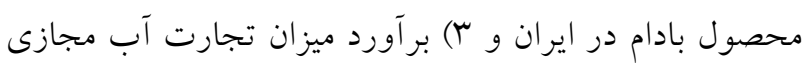
اين محصول از كشور است.

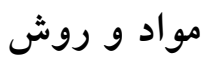

در اين ئزوهش، اطلاعات مربوط به سطح زير كشـت، عملكـــد

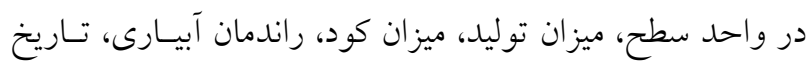

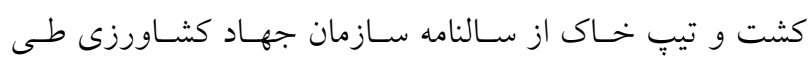

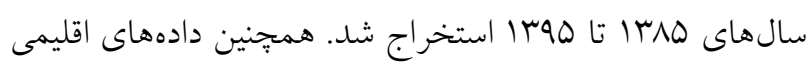

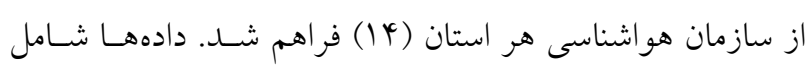

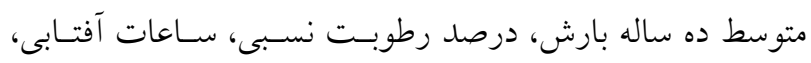

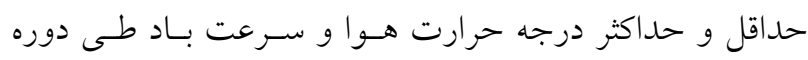
آمارى مورد مطالعه است.

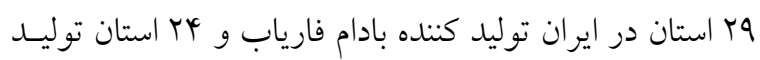

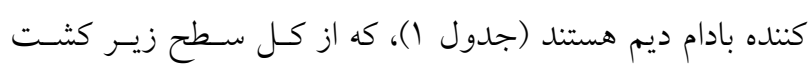

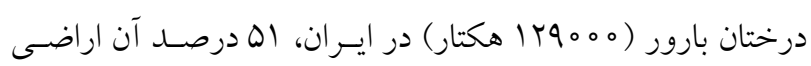
فارياب و مابقى آن بهصورت ديم كشت مىشودو. اين استـانهـا

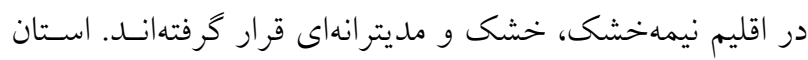
جهارمحال و بختيارى با متوسط بارش سـالانه 991 ميلسى متسر و و

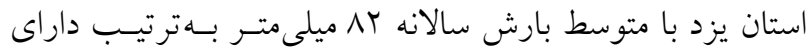
بيشترين و كمترين ميران بارش در بين استانهـاى توليـد كنــــه بادام در ايران هستند (19). 
نشريه علوم آب و خاك / سال بيست و جهارم / شماره دوم / تابستان 99『1

جدول ا. اطلاعات محصول توليدى در استانهاى توليد كننده بادام ديم و فارياب در ايران

\begin{tabular}{|c|c|c|c|c|c|c|c|c|c|c|c|c|}
\hline \multicolumn{2}{|c|}{ (تن در هكتار ) } & \multicolumn{2}{|c|}{ 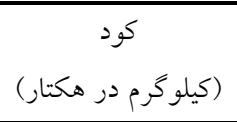 } & \multicolumn{2}{|c|}{ سهم ملى (درصد) } & \multicolumn{2}{|c|}{ ستمم در سطح } & \multicolumn{3}{|c|}{ توليد } & \multirow[t]{2}{*}{ كد } & \multirow[t]{2}{*}{ استان } \\
\hline ديم & آبى & ديم & آبى & ديم & آبى & ديم & آبى & كل & ديم & آبى & & \\
\hline$\circ / 0$ & $1 / r$ & id & Qr & $1 / Q T$ & $V / I^{4}$ & V & $9 \pi$ & $V y=1$ & par & 9909 & 1 & آذربايجان شرقى \\
\hline $0 / 9$ & $1 / 0$ & YQ & $\Delta \wedge$ & $0 / 91$ & $\mu / \circ 9$ & 4 & 94 & MIOV & 191 & r909 & r & آذربايجان غربى \\
\hline$\circ / 4$ & $1 / r$ & id & $\Delta Q$ & o/AT &.$/ 11$ & Q9 & ky & YYY & Iry & $1 \circ \mathrm{V}$ & $r$ & 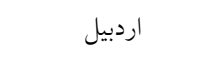 \\
\hline$\circ / 0$ & $1 / r$ & ro & qV & $1 / 00$ & $\mathrm{~V} / \mathrm{II}$ & $\Delta$ & 90 & VTTS & ma & GMMG & r & اصفهان \\
\hline$\circ / 0$ & $1 / 9$ & r。 & $\Delta \Delta$ & \%०r & $\circ / \Gamma \Delta$ & 1 & 99 & MYl & $\Delta$ & (MTS & 0 & 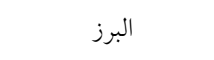 \\
\hline$\circ / V$ & $\circ / N$ & YQ & $\Delta \varphi$ & $\circ / V Y$ &.$/ 14$ & 99 & ry & rot & ret & IKr & 4 & ايلام \\
\hline- & $r / 9$ & ro & 01 &.$/ 01$ & o/ T & 9 & 91 & $1 \wedge$ & r & IV & v & بوشهر \\
\hline- & r & YQ & 01 & - & $\circ / Q 4$ & - & 100 & 011 & - & 011 & $\wedge$ & ت ت تهران \\
\hline- & $1 / 9$ & ro & Qr & - & $0 / T_{0}$ & - & 100 & 194 & - & $19 r$ & 9 & جنوب كرمان \\
\hline$\circ / 0$ & $1 / N$ & id & $\Delta r$ & $\circ / T \Delta$ & IY/Ar & 1 & 99 & $\mid$ kftu & $\wedge r$ & $14 r k 9$ & 10 & جهارمحال و بختيارى \\
\hline$\circ / 0$ & $1 / 4$ & $\forall Q$ & or & $10 / 91$ & 9109 & ऍ & Gr & qrat & rorl & $\Delta \wedge \& \Gamma$ & 11 & خراسان جنوبى \\
\hline$\circ / \mu$ & $\circ / \wedge$ & YQ & $\Delta Q$ & $I V / 0 D$ & G/VV & is & QY & $I T \circ \Delta V$ & $\Delta \Delta \cdot 1$ & 9009 & IT & خراسان رضوى \\
\hline $0 / 9$ & $r / 4$ & ro & $\Delta V$ & $Y / \Lambda \circ$ & $1 / 79$ & $ه \Delta$ & YQ & rVQA & 1000 & ITYA & ir & خراسان شمالى \\
\hline $1 / 1$ & $r / Q$ & ro & or & $\circ / Y \Lambda$ &.$/ 11$ & $q v$ & or & 194 & 91 & lor & If & 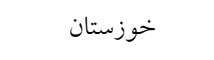 \\
\hline$\circ / 0$ & $1 / 0$ & ro & $\Delta V$ & $0 / \pi$ & I/NG & 4 & 94 & $|v q|$ & 109 & $19 \wedge 0$ & 10 & ز زنجان \\
\hline- & $1 / 0$ & $Y Q$ & Qr & ./०r & $1 / \pi \Delta$ & 1 & 99 & $|M| \Lambda$ & 9 & $\| r \circ \Lambda$ & 19 & سمنان \\
\hline$\circ / 1$ & $1 / 9$ & ro & 01 & - & $\circ / Y Y$ & - & 100 & rrv & - & TrV & IV & سيستان و بلوجستان \\
\hline$\circ / V$ & r & YQ & $\Delta \wedge$ & $Y K / \Lambda F$ & $14 / 10$ & or & rV & TVYOl & $\mid$ KEV & IrVT。 & 11 & فارس \\
\hline$\circ / 4$ & 1 & ro & $\Delta V$ & $V / N I$ & $9 / 0 \circ$ & TV & $v^{r}$ & $\wedge \varphi 0^{\circ}$ & rroq & aral & 19 & قزوين \\
\hline $0 / 1$ & $1 / 1$ & $\psi Q$ & $\Delta r$ & .01 & o/Ar & $\circ$ & 100 & 1०。 & r & $\vee 91$ & ro & قم \\
\hline $0 / 9$ & $1 / 1$ & ro & $\Delta V$ & $1 / 09$ & $\circ / Q F$ & rq & 91 & 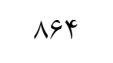 & MYl & QTr & rl & كردستان \\
\hline$\circ / \mu$ & $1 / 1$ & YQ & $\Delta \Delta$ & $r / \circ Y^{r}$ & $9 / 19$ & 9 & 91 & VTrM & 901 & 9990 & Tr & كرمان \\
\hline$\circ / 0$ & $r / 1$ & \&Q & $\Delta 9$ & $|/ N|$ & $r / \Psi V$ & 10 & $\wedge \Delta$ & rque & $\Delta \wedge Q$ & M Mat & r & كرمانشاه \\
\hline$\circ / \wedge$ & $1 / r$ & $\forall Q$ & 90 &.$/ 94$ & $\circ / N 1$ & r & VV & $\wedge 9 \vee$ & $r \circ \Delta$ & 994 & TY & كهيلويه و بويراحمد \\
\hline$\circ / \mu$ & $1 / r$ & YQ & 90 & $0 / 4 r$ & $r / 09$ & 0 & 90 & r901 & 140 & TQII & ro & ل ل ل لرستان \\
\hline$\circ / 4$ & $1 / 1$ & $\forall Q$ & $\Delta H^{F}$ & $\circ / \mu$ & $\Delta / 4 D$ & r & 91 & $\Delta Y 01$ & IYY & OrVV & YG & مركزى \\
\hline$\circ / 1$ & $1 / 0$ & ro & Qr & ०/० & $\circ / V 9$ & 1 & 99 & 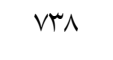 & 9 & Vrr & TV & هرمز كان \\
\hline$\circ / 0$ & $1 / 4$ & $Y Q$ & $\Delta V$ & $r / T Q$ & t/Fr & ro & $\Lambda^{\circ}$ & Draq & 1011 & FTM & $r \Lambda$ & 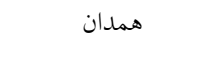 \\
\hline $0 / r$ & $\circ / 0$ & ro & 01 &.$/ 1 \mathrm{r}$ & $r / 94$ & 1 & 99 & rosq & rı & rors & rq & 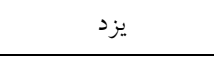 \\
\hline- & - & 100 & 100 & 100 & 100 & 100 & 100 & $1 Y 9094$ & TTVY & aVVar & - & كل \\
\hline.$/ 19$ & $1 / 4 v$ & $|4|$ & $\Delta F$ & - & - & - & - & - & - & - & - & ميانخين \\
\hline$\circ / 1$ & $\circ / 0$ & YQ & 90 & $k+/ \Lambda F$ & IY/Ar & 99 & 100 & I krukg & $\mid$ KEV & TVYOl & - & ماكزيمم \\
\hline$\circ / \Lambda$ & $r / l$ & ro & \&V & ०/०r & $\circ / 11$ & 1 & ry & IV & r & 11 & - & مينيمم \\
\hline
\end{tabular}


سبز در كشـت ديـم نشـان مسىدهـد، اسـتانهـاى كهيلويسه و

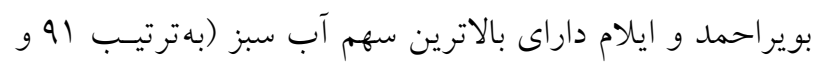

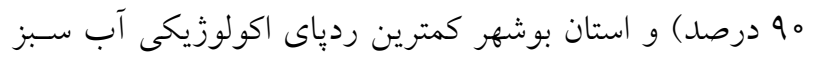
را دارد ( سب درصد) (شكل (1). لذا در بررسى ردياى اكولوزيكى آب سبز، در اراضسى ديسـم و

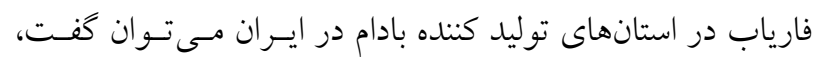

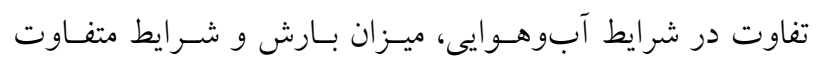

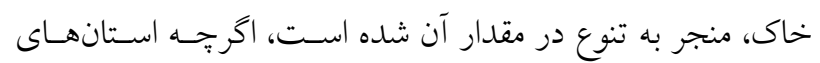
غربى و جنوب غربى بهدليـل بـارش مناسـب داراى بـارش مـؤثر

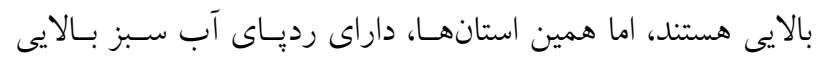

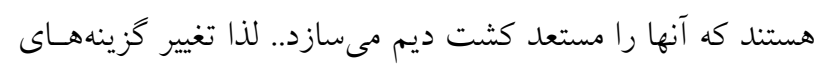
مديريتى در مرحله كاشت، داشت و بهكارگيرى سامانههاى آبخيـر

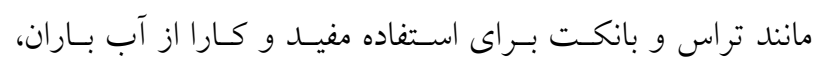

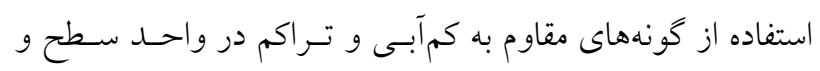

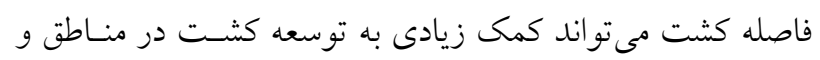

تبديل اراضى بادام فارياب به ديم كند (19).

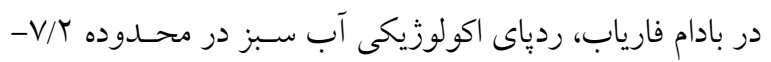

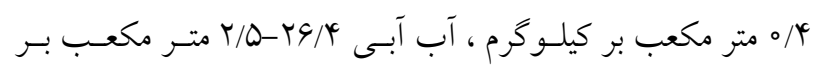

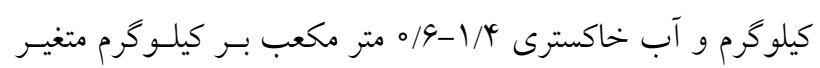

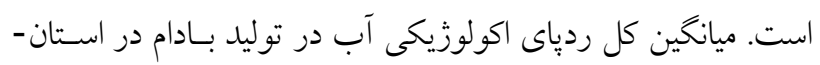
هاى متتخب أ11/ متر مكعب بر كيلوكرم است كه از اين مقدار 19

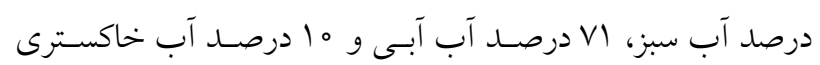

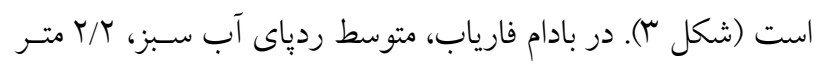

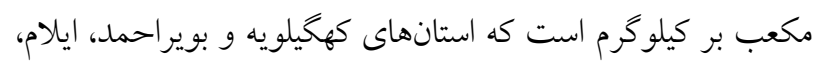

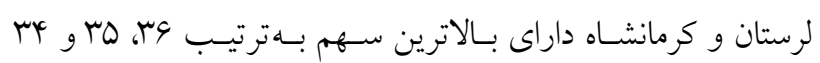

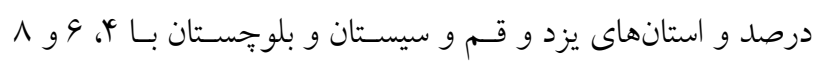

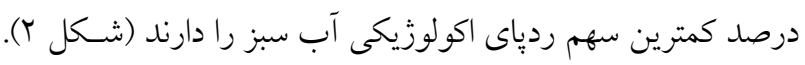

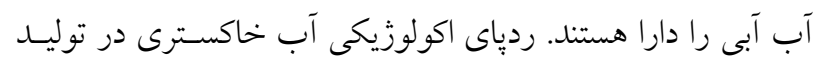

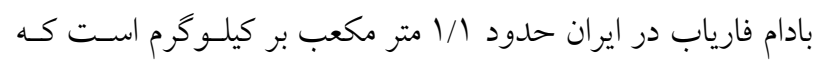

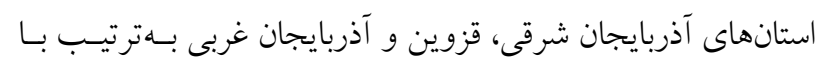

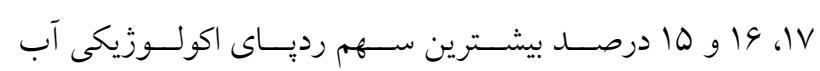

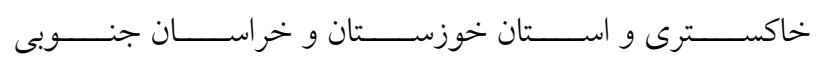

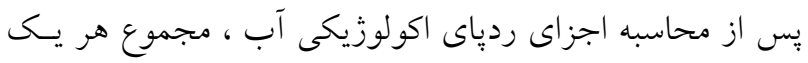

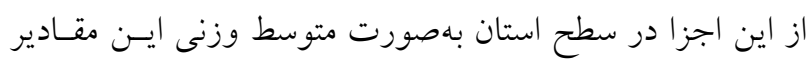
با استفاده از روابط زير محاسبه شد:

$\mathrm{WFV}_{\mathrm{i}, \mathrm{x}}=\operatorname{Prod}_{\mathrm{i}, \mathrm{x}} \mathrm{WF}_{\mathrm{i}, \mathrm{x}} \mathrm{i}=1, \ldots, 29$

$\mathrm{AWF}_{\mathrm{i}, \mathrm{x}}=\frac{\alpha_{\mathrm{i}} \mathrm{WFV}_{\mathrm{i}, \mathrm{x}}}{\alpha_{\mathrm{i}} \operatorname{Prod}_{\mathrm{i}, \mathrm{x}}}$

كه در آنها، i شاخص محصول، Xزء x رديـاى اكولـوزيكى آب

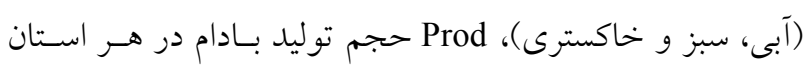

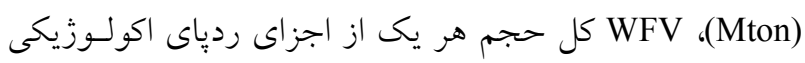

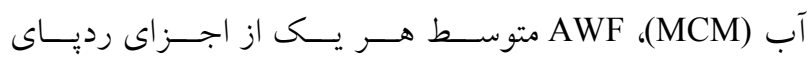

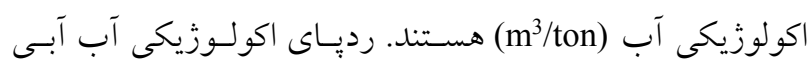
براى بادام ديم محاسبه نمىشود.

ميـزان آب مجـازى صـادر شــهـ content exported) ردياى اكولوزيكى عبارتست از: اختلاف كل حجم اجزاى ردياى

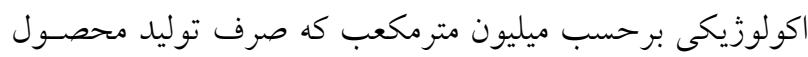

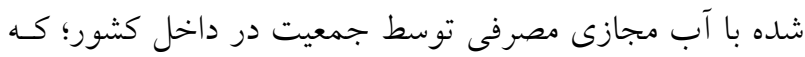

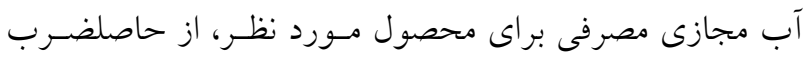

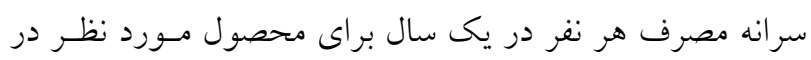

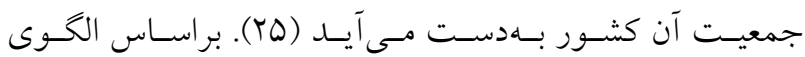

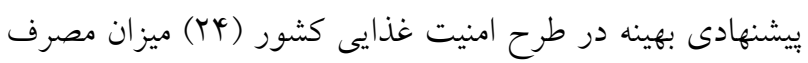

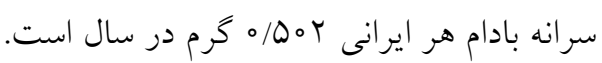

نتايج و بحث ردياى اكولوزيكى آب در بادام ديـم و فاريـاب در ايسران و استانهاى توليد كننده

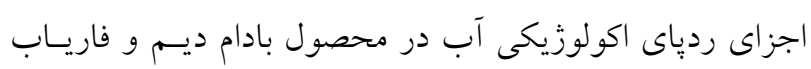

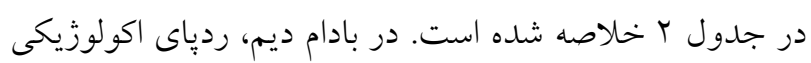
آب سبز در محدوده

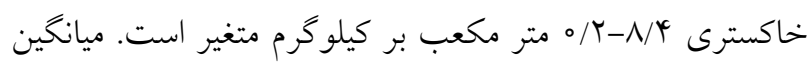

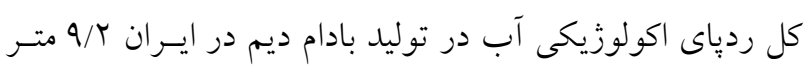

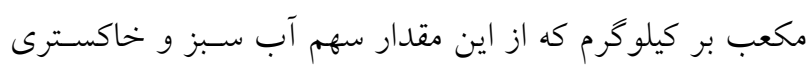

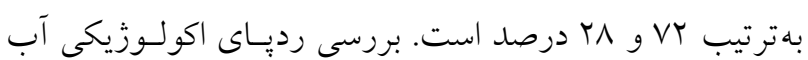


نشريه علوم آب و خاك / سال بيست و جهارم / شماره دوم / تابستان 99『1

جدول ז. اجزاى ردياى اكولوزيكى آب در بادام ديم و فارياب در استانهاى توليد كنده بادام در ايران

\begin{tabular}{|c|c|c|c|c|c|c|c|}
\hline \multicolumn{4}{|c|}{ ردياى اكولوزيكى آب در بادام فارياب (متر مكعب بر كيلوگرم) } & \multicolumn{3}{|c|}{ ردياى اكولوزيكى آب در بادام ديم (متر مكعب بر كيلوكرم) } & \multirow[t]{2}{*}{ | (استان } \\
\hline كل & خاكسترى & آبى & سبز & كل & خاكسترى & سبز & \\
\hline rN/r & $9 / 4$ & $r q / 4$ & $\Delta / 4$ & 14 & $\varphi / V$ & $9 / \Gamma$ & آذزبايجان شرقى \\
\hline $10 / 9$ & $1 / V$ & $0 / 9$ & $\mu / \mu$ & $10 / 1$ & $1 / 1$ & $9 / \mathrm{V}$ & 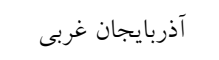 \\
\hline $10 / \pi$ & 1 & $4 / 1$ & $r / 4$ & $0 / 9$ & 1 & $4 / 9$ & اردبيل \\
\hline$\Lambda / 9$ & $\circ / 4$ & $\mathrm{~V} / \mathrm{r}$ & $1 / r$ & $9 / 9$ & r & $r / 9$ & اصفهان \\
\hline$r / 9$ & $\circ / 1$ & $r / 4$ & $1 / 1$ & $\mu / \Lambda$ & $\circ / 4$ & $r / V$ & 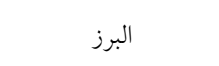 \\
\hline$r \circ / r$ & $T / Y$ & $10 / 1$ & $V / r$ & $\Delta / r$ & $\circ / 0$ & $\psi / \Lambda$ & 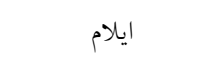 \\
\hline $9 / 9$ & $\circ / r$ & $0 / 9$ & $\circ / \wedge$ & $|r /|$ & $N / r$ & $r / 9$ & بوشهر \\
\hline$r / r$ & $\circ / 1$ & $r / Q$ &.$/ 9$ & - & - & - & 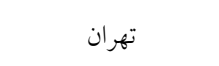 \\
\hline$\Lambda / r$ & $0 / r$ & $V / I$ &.$/ 9$ & - & - & - & جنوب كرمان \\
\hline $9 / \pi$ & $\circ / r$ & $\varphi / 4$ & $1 / V$ & $9 / 9$ & $1 / 4$ & $Q / 4$ & جهارمحال و بختيارى \\
\hline$V / I$ & $\circ / \mu$ & $0 / 9$ &.$/ 9$ & $r / 4$ & 1 & $r / 4$ & خراسان جنوبى \\
\hline $14 \pi$ & $1 / 4$ & $10 \pi$ & $r / 9$ & $19 / \pi$ & $\Lambda / 4$ & $10 / 9$ & خراسان رضوى \\
\hline $11 / r$ & 1 & $\mathrm{~V} / \mathrm{A}$ & $r / 0$ & $19 / \pi$ & $V / I$ & $9 / r$ & خراسان شمالى \\
\hline$r / 9$ & $\circ / 1$ & $r / 4$ & $\circ / 4$ & $\circ / V$ & $\circ / Y$ & $\circ / 0$ & خ خوزستان \\
\hline $1 Y / 9$ & $1 / 9$ & $\mathrm{~V} / \mathrm{A}$ & $r / r$ & $10 / 9$ & $r / l$ & $1 \% / 0$ & ز \\
\hline $9 / V$ & $0 / r$ & $\Delta / N$ & $\circ / \wedge$ & - & - & - & 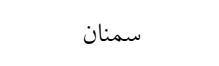 \\
\hline $9 / 4$ & $0 / r$ & $\Delta / \Lambda$ & $\circ / 4$ & - & - & - & سيستان و بلوجستان \\
\hline$\Delta / 4$ & $0 / r$ & $4 / 1$ & $1 / 1$ & $\mu / \mu$ & $\circ / 9$ & $r / \mathcal{r}$ & فارس \\
\hline$r \mid / 4$ & $r / \Delta$ & ir & $4 / 9$ & $V / V$ & $1 / r$ & $9 / 4$ & ق ق قزوين \\
\hline $1 T / 9$ & 1 & $10 / 1$ & $1 / 1$ & - & - & - & قم \\
\hline 10 & $\circ / \wedge$ & 4 & $r / r$ & $v / r$ & $\circ / 9$ & $9 / 4$ & كردستان \\
\hline ir & $\circ / \wedge$ & $10 / 1$ & $1 / 4$ & $1 Y / 9$ & $V / r$ & $\Delta / Y^{4}$ & كرمان \\
\hline$r / V$ & $0 / r$ & $r / 9$ & $1 / 9$ & $1 V / 9$ & $V / 9$ & $9 / 1$ & كرمانشاه \\
\hline $10 / N$ & $r / r$ & $\mathrm{~V} / \mathrm{V}$ & $\Delta / V$ & $V / q$ & $\circ / V$ & $V / T$ & كهكيلويه و بويراحمد \\
\hline$\Lambda / \Lambda$ & $\circ / 0$ & $\Delta / r$ & r & $1 \pi / r$ & $r / 4$ & $10 / 1$ & ل ل لرستان \\
\hline $9 / 1$ & $\circ / 0$ & $9 / 4$ & $r / T$ & $\Lambda / V$ & $T / Y$ & $9 / 0$ & مركزى \\
\hline$K r / r$ & $\circ / 0$ & $10 / V$ & $1 / 1$ & - & - & - & 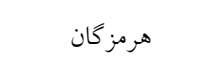 \\
\hline$\Lambda / r$ & $0 / 9$ & $\Delta / r$ & $r / r$ & $9 / 9$ & $T / Y$ & $V / V$ & همدان \\
\hline$r \& / \Lambda$ & $4 / 1$ & $r 1 / 9$ & $1 / 1$ & $r / q$ & $1 / \wedge$ & $1 / T$ & يزد \\
\hline $11 / 4$ & $1 / 1$ & $\wedge$ & $T / Y$ & $9 / r$ & $r / 9$ & $9 / 4$ & ميانگين \\
\hline$r \Lambda / r$ & $9 / 4$ & $r q / 4$ & $V / r$ & $19 / r$ & $\Lambda / 4$ & $1 \pi / 0$ & ماكزيمم \\
\hline$r / r$ & $\circ / 1$ & $r / Q$ & $0 / 4$ & $\circ / V$ & $0 / r$ & $\circ / 0$ & مينيمم \\
\hline
\end{tabular}


آب خاكسترى ها آب سبزه

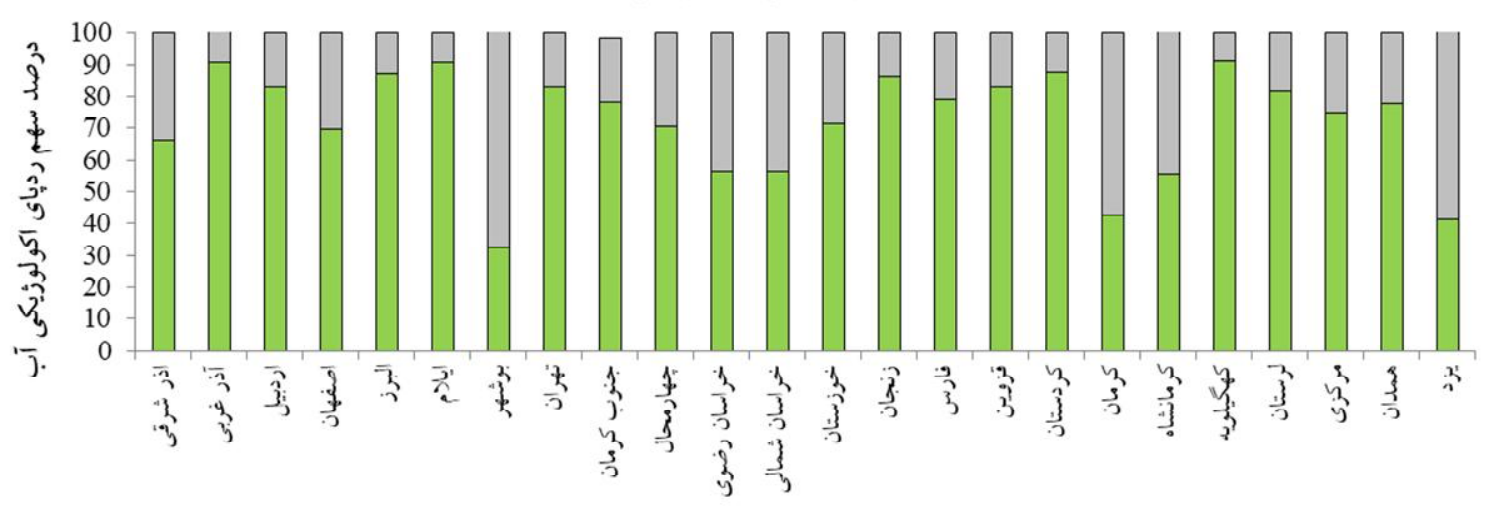

شكل ا. سهم اجزاى ردياى اكولوزيكى آب در بادام ديم در استانهاى توليد كنده بادام در ايران (رنخى در نسخه الكترونيكى) آب خاكسترى ه آب آبى آب سبزه

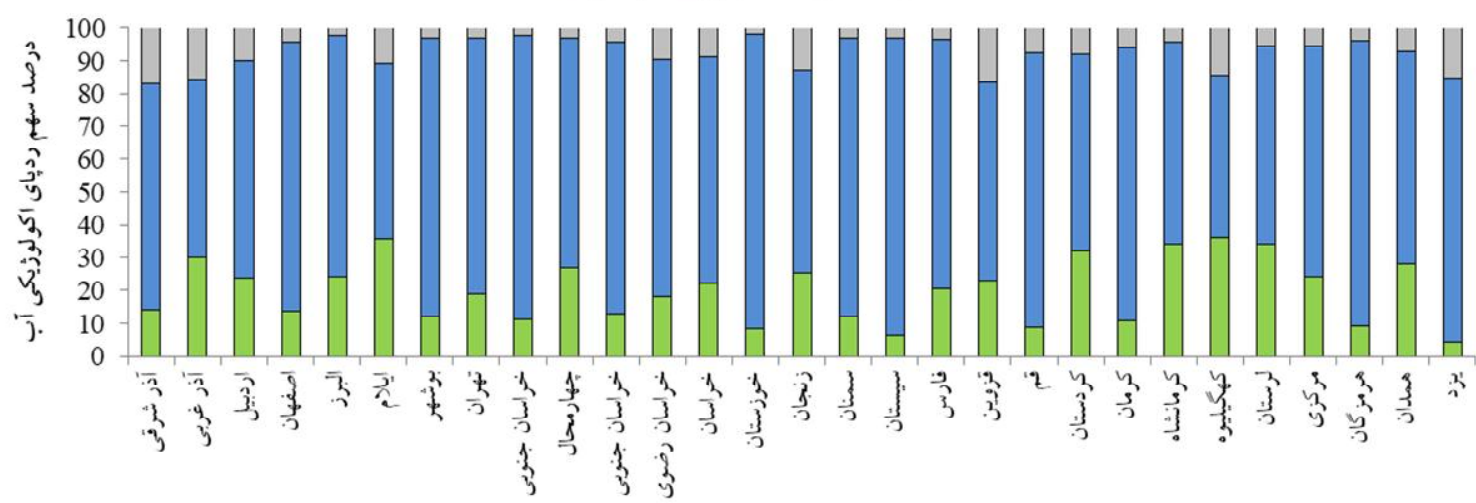

شكل r. سهم اجزاى ردياى اكولوزيكى آب در بادام فارياب در استانهاى توليد كنده بادام در ايران (رنكى در نسخه الكترونيكى)

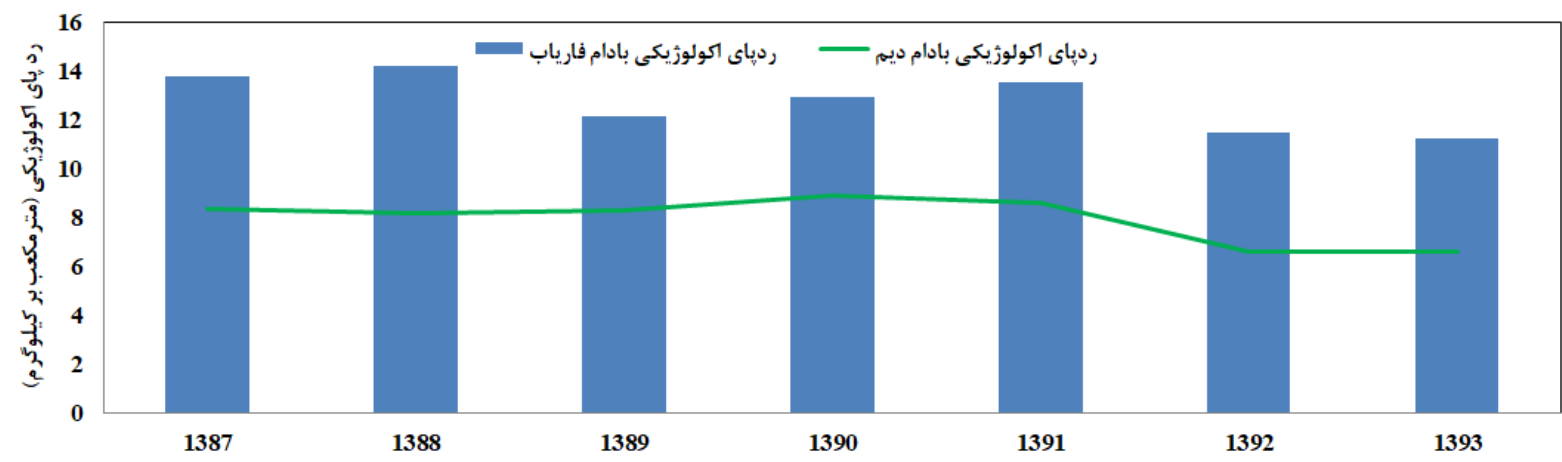

شكل r. تغييرات زمانى اجزاى ردياى آب در محصول بادام ديم و فارياب در ايران (رنغى در نسخه الكترونيكى)

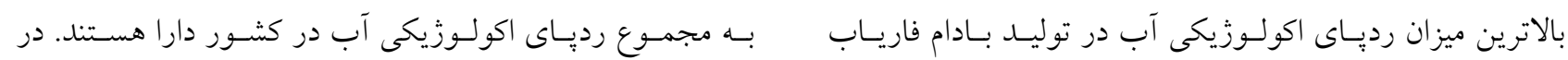

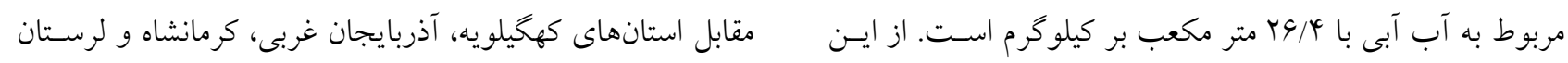

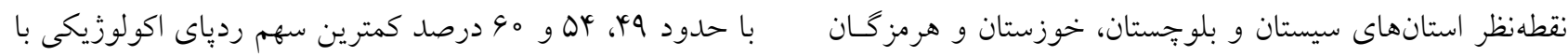

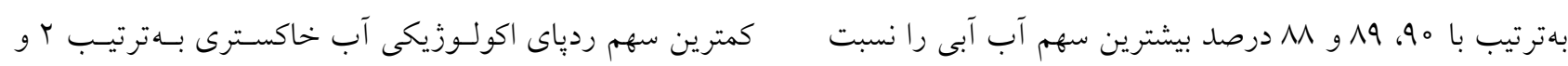




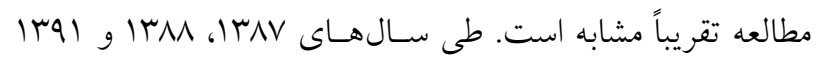

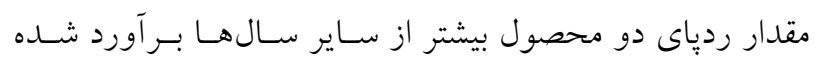

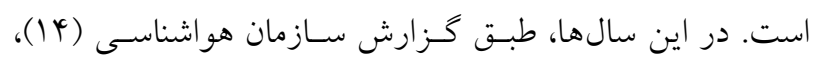

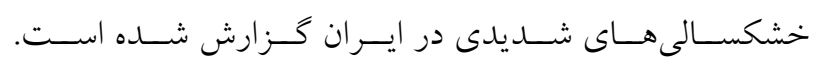

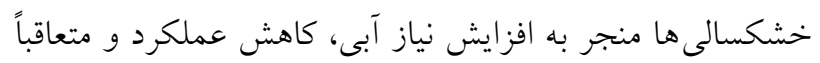

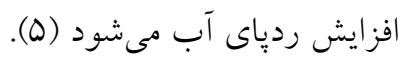

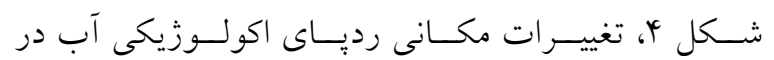
محصـول ديـم و فاريـاب را در ايسران در ب ب اسـتان نمـايش

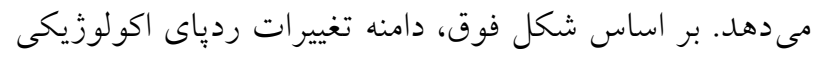

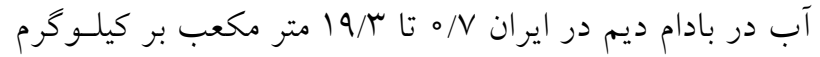

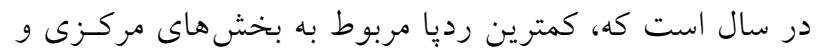
جنوب غربى ايران و بيشترين رديا مربوط به بخشهاى شـمال

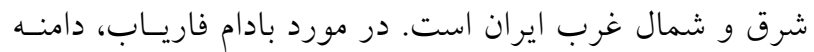

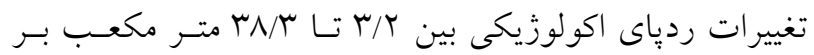
كيلو گرم در سال است كـه عمـوم منـاطق كشـور در محسـوديه

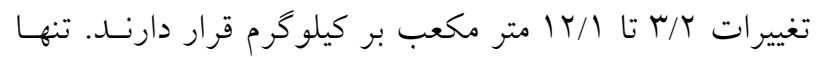

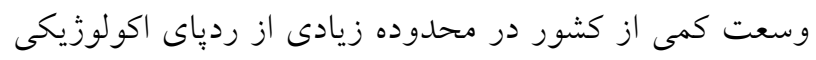

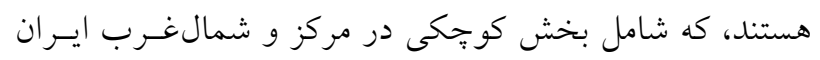

حجم آب مجازى و تجارت آب مجازى در محصـول بـادام ديم و فارياب در مقياس ملى و استانى

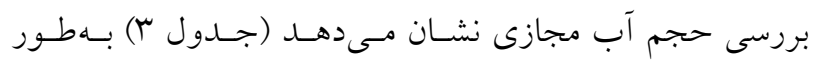

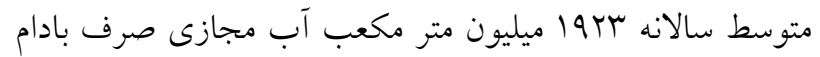

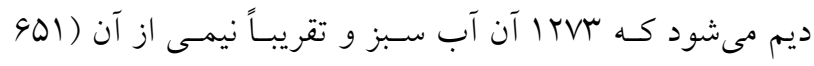

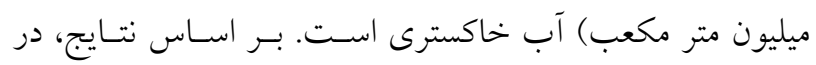

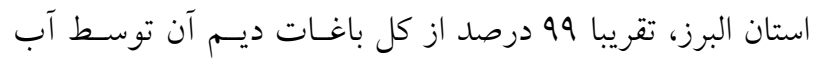

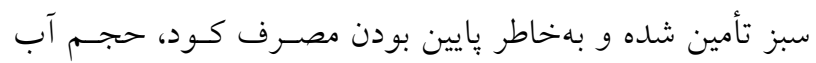

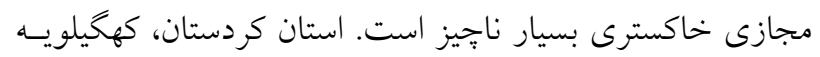

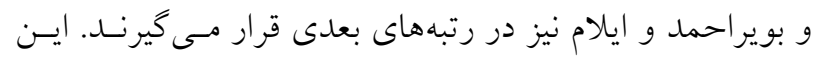

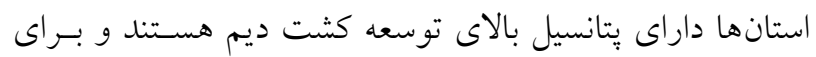
توسعه كشت ديم در آنها بايستى سازمانهاى متولى امر، بهدنبال
( T/K درصد را دارا هستند.

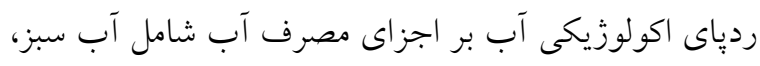

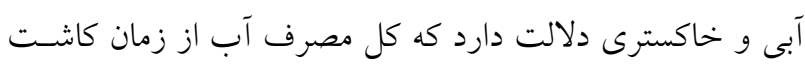

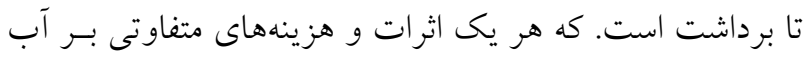

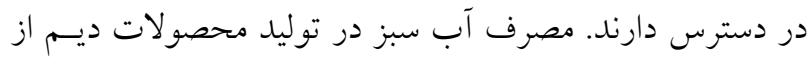

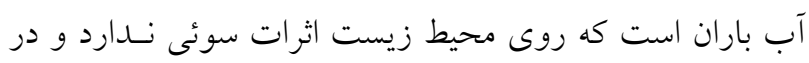

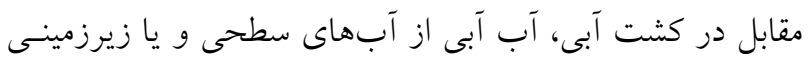

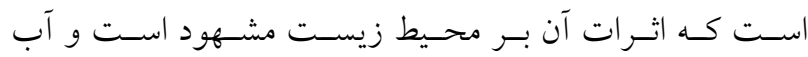

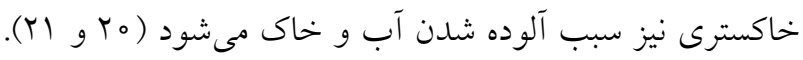

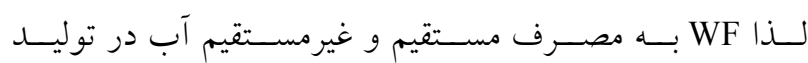
محصولات كشاورزى و اثرات زيستمحيطى ناشسى از آن دارد

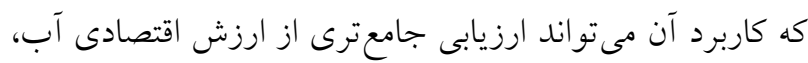
بهروورى آب زراعى و اولويتبندى زمانى و مكانى كشت به مـا.

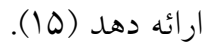
متوسط كل ردياى اكولوزيكى آب در توليـــــــادام در ايـران

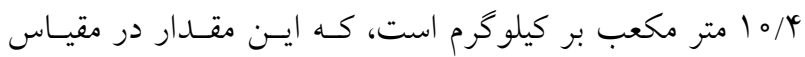

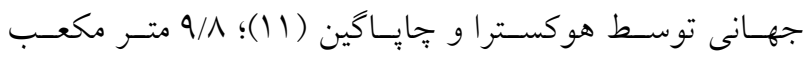

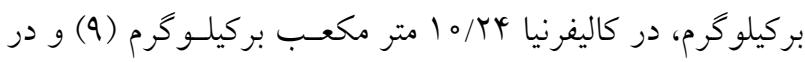

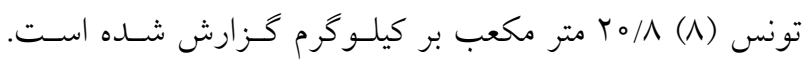
تفاوت در مديريت كاشت، داشت و برداشت، مصرف كود زيـاد

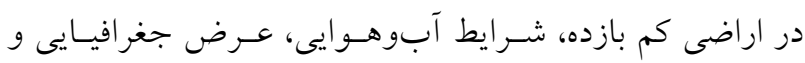

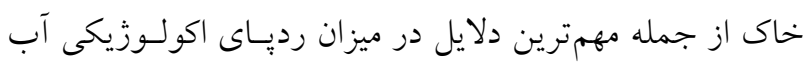
در نواحى مختلف است.

تغييرات زمانى و مكانى ردياى اكولوزيكى آب در محصسول ديم و فارياب بادام در ايران

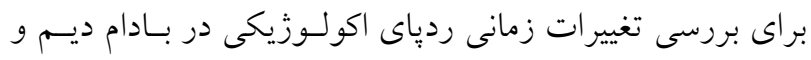

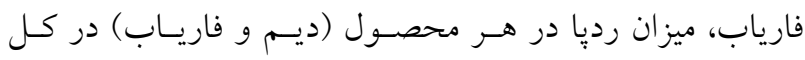

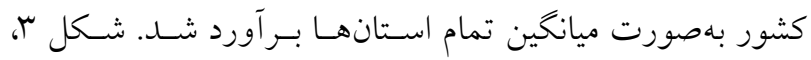

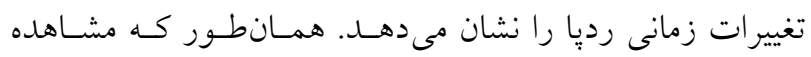

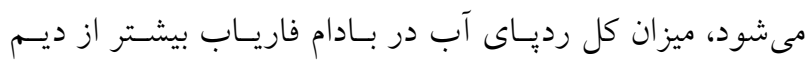

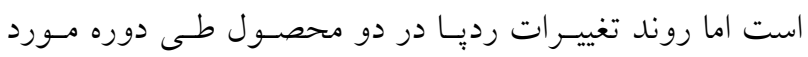



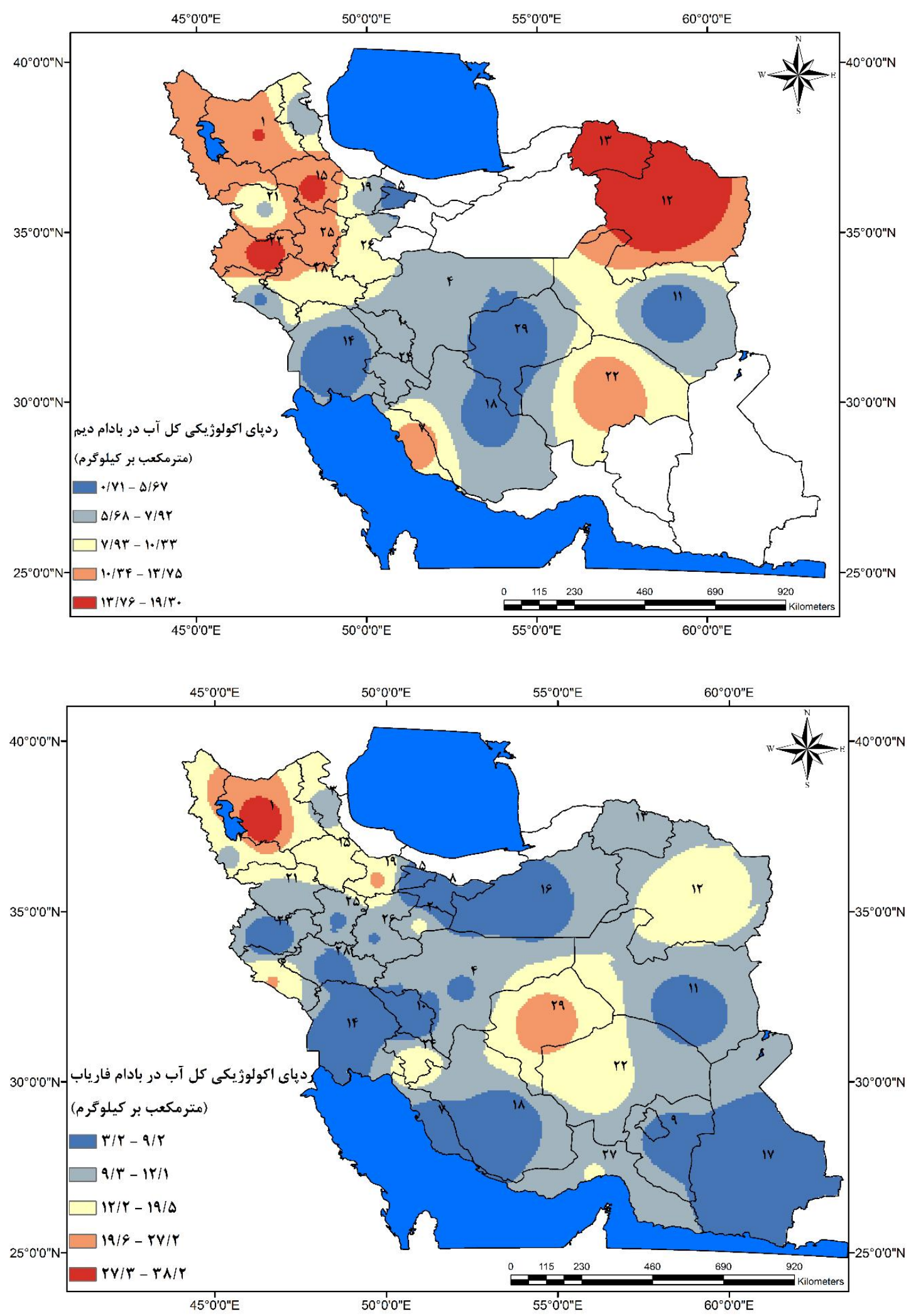

شكل †. تغييرات مكانى اجزاى ردياى آب در محصول بادام ديم و فارياب در ايران (كد هر استان در جدول الارائه شده است.) (رنخى در نسخه الكترونيكى) 
جدول r. متوسط حجم آب مجازى در بادام ديم و فارياب در استانهاى توليد كنده بادام در ايران

\begin{tabular}{|c|c|c|c|c|c|c|c|c|c|}
\hline \multicolumn{2}{|c|}{ سهم ملى (درصد) } & \multicolumn{4}{|c|}{ كل حجم آب مجازى در بادام فارياب } & \multicolumn{3}{|c|}{$\begin{array}{c}\text { كل حجم آب مجازى در بادام ديم } \\
\text { (ميليون متر مكعب) }\end{array}$} & \multirow[t]{2}{*}{ استان } \\
\hline آبيارى & ديم & 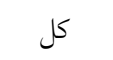 & خاكسترى & آبى & سبز & كل & خاكسترى & سبز & \\
\hline$r T / 4$ & $r / Q$ & $1 \wedge \% q / V$ & $r \circ \Lambda / l$ & IrVq/1 & TEY/D & $\Psi N / 1$ & $19 / 1$ & rT & آذربايجان شرقى \\
\hline$r / V$ & $\circ / \wedge$ & $r T Q / Y$ & $r \Delta / \Delta$ & $\mid r T / 1$ & $9 V / 9$ & $14 / 9$ & $1 / 0$ & $1 \pi / 4$ & آذربايجان غربى \\
\hline$\circ / 1$ & $0 / r$ & $V / 9$ & $\circ / V$ & $0 / 1$ & $1 / 1$ & $Q / Q$ & 1 & $4 / 9$ & اردبيل \\
\hline $0 / 1$ & $\circ / \wedge$ & kyY & $1 V / 9$ & $r \omega \circ / r$ & $\Delta Q / 9$ & $10 / V$ & $\varphi / \Lambda$ & $10 / 9$ & اصفهان \\
\hline$\circ / 1$ & $\%$ & $\mathrm{~V} / \mathrm{\Lambda}$ & $0 / r$ & $Q / V$ & $1 / 9$ & $\circ / 1$ & $0 / 001$ & $\circ / 1$ & 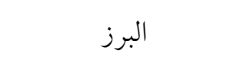 \\
\hline $0 / r$ & $0 / 4$ & $\mathrm{IV} / \mathrm{r}$ & $1 / 9$ & $9 / r$ & $9 / \pi$ & $1 / 9$ & $\circ / \Lambda$ & $\Lambda / \wedge$ & ايلام \\
\hline $0 / 01$ & $0 / 01$ & $\circ / V$ & $0 / 001$ & $0 / 9$ & $\circ / 1$ & $0 / T$ & $\circ / 1$ & $\circ / 1$ & بوشهر \\
\hline$\circ / 1$ & - & $11 / V$ & $\circ / r$ & $9 / r$ & $r / \mu$ & - & - & - & ت تهران \\
\hline$\circ / 1$ & - & $11 / r$ & $\circ / \mu$ & $9 / 9$ & $1 / \pi$ & - & - & - & جنوب كرمان \\
\hline$V / V$ & $0 / r$ & $G K r / 1$ & $r Y / 0$ & $\{x+/ 1$ & $19 \mathrm{~V} / 0$ & $r / 9$ & $\circ / \Lambda$ & $\mu / \Lambda$ & جهارمحال و بختيارى \\
\hline$r / \Delta$ & $\mu / \mu$ & rAq & $10 / 9$ & TYY/K & $r q / 1$ & $\Lambda \mu / \Delta$ & $r y / \mu$ & $\Delta Q / r$ & خراسان جنوبى \\
\hline$\Lambda / 1$ & rN/9 & $90 \mathrm{~V} / \mathrm{r}$ & $q 4 / T$ & $k V \mid / s$ & $|r| / 0$ & $V \mid+1 / Q$ & MTY/F & $419 / r$ & خراسان رضوى \\
\hline $1 / r$ & $9 / r$ & $99 / 4$ & $\Lambda / \vee$ & $9 \Lambda / 0$ & $r Y / r$ & IVV & $\mathrm{V} / \mathrm{A}^{\mathrm{c}}$ & $99 / 9$ & خراسان شمالى \\
\hline $0 / 01$ & $0 / 01$ & $r / \Delta$ & $\circ / 1$ & $\mu / 1$ & $\circ / \mu$ & $\circ / 0$ & $\circ / 1$ & $\circ / \mu$ & خوزستان \\
\hline $1 / \wedge$ & $0 / 9$ & 140 & $|\Lambda /|^{k}$ & $91 / \mathrm{N}$ & $r V / q$ & $11 / 9$ & $1 / 0$ & 10 & 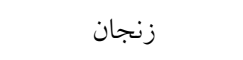 \\
\hline$\circ / V$ & - & $91 / 4$ & $T / Y$ & $\Delta T / \mu$ & $9 / 9$ & - & - & - & سمنان \\
\hline$\circ / 1$ & - & $10 / 9$ & $\circ / \mu$ & $9 / 9$ & $\circ / V$ & - & - & - & سيستان و بلوجِستان \\
\hline $0 / 9$ & $r Y / r$ & $r \wedge r / q$ & $10 / r$ & $r \& \mathrm{~V} / \mathrm{Q}$ & $10 Y / 1$ & $\mu \mu_{0} / D$ & $19 / 4$ & $m<1 / 1$ & فارس \\
\hline $11 / 4$ & $9 / 9$ & $9 k r / \Lambda$ & $\mid Q \psi / \Lambda$ & $\Delta V Y / \Delta$ & TIV/D & IrE/V & $r \circ / V$ & 1.9 & قزين \\
\hline$\circ / 9$ & $0 / 01$ & $V T / Y$ & $\mathrm{Q} / \Lambda$ & $90 / 1$ & $9 \pi$ & $\circ \%$ & $\circ / \circ$ & $\circ \%$ & قم \\
\hline$\circ / 4$ &.$/ 9$ & re/v & $r / 9$ & $r Y / l$ & $11 / \mathrm{V}$ & $|V /|^{c}$ & $r / l$ & $10 / r$ & كردستان \\
\hline$V / r$ & $r$ & $900 / 4$ & $r \Delta / r$ & $0.1 / \wedge$ & $q \pi / 1$ & $\Delta \wedge$ & س & ro & كرمان \\
\hline $1 / 4$ & $r / \Lambda$ & $11 \% / 1$ & $r$ & $99 / 4$ & r// & $V T / r$ & $M r / Y$ & $4 \circ / 1$ & كرمانشاه \\
\hline$\circ / 9$ & $0 / 9$ & $v 9 / 1$ & $11 / r$ & $M V / \mu$ & $r V / Q$ & $11 / r$ & 1 & $10 / 4$ & كهكيلويه و بويراحمد \\
\hline $1 / 9$ & $\circ / V$ & $10 r / 9$ & $\wedge$ & $9 \pi / 1$ & $\Delta T / 1$ & ir & $r / 4$ & $10 / 9$ & 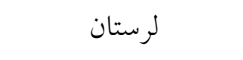 \\
\hline$r / 1$ & $\circ / 4$ & MUt/l & $I V / F$ & rms/9 & $\Lambda \circ / 1$ & $V / D$ & $1 / 9$ & $0 / 9$ & 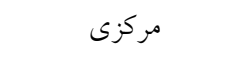 \\
\hline$\circ / \Lambda$ & - & $9 Y / \Lambda$ & $r / Q$ & $\Delta r / q$ & $0 / 4$ & - & - & - & هرمز كان \\
\hline$r$ & $r / 9$ & YYV/A & $\mid N / 4$ & $109 / \mathrm{V}$ & $99 / \mathrm{V}$ & $V \psi^{*} / \Lambda$ & $19 / 1$ & $\Delta V / 9$ & همدان \\
\hline$\wedge$ & - & $995 / 9$ & $10 T / r$ & & $r V / r$ & $\circ / \wedge$ & $\circ / 0$ & $\circ / \mu$ & 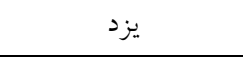 \\
\hline 100 & 100 & NTYY & $\wedge 9 \Lambda / \wedge$ & $\Delta \wedge \Lambda 1$ & $1 K q T / T$ & $19 \pi / r$ & $900 / 1$ & ITVY/O & مجموع \\
\hline- & - & $r \wedge Y / r$ & ro & $r \circ r / \Lambda$ & $01 / 0$ & $10 / 1$ & $r V / l$ & or & ميانخين \\
\hline$r Y / 4$ & MN/9 & $1 \wedge k 9 / V$ & $r \circ \Lambda / 1$ & IrVq/1 & TEY/D & $V+1 / Q$ & MTY/Y & $419 / r$ & ماكزيمم \\
\hline $0 / 01$ & $0 / 01$ & $\circ / V$ & $\circ / 1$ & $0 / 9$ & $\circ / 1$ & $\circ / 1$ & $0 / 001$ & $\circ / 1$ & مينيمم \\
\hline
\end{tabular}


حجم آب بركشت يذير در ايران، سالانه ده درصد از اين حجم صرف توليد بادام در ايران مىشود.

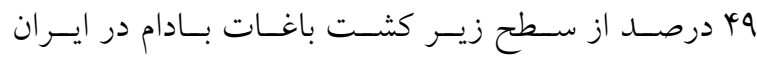

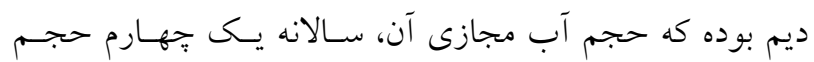

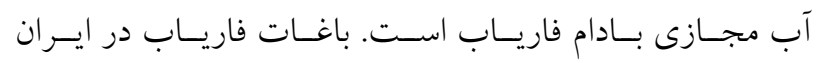

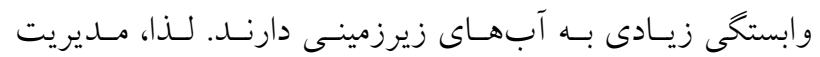

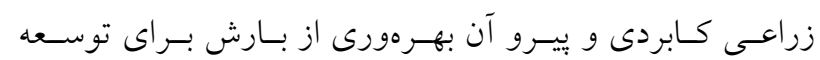

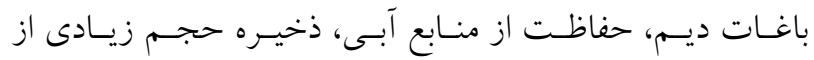

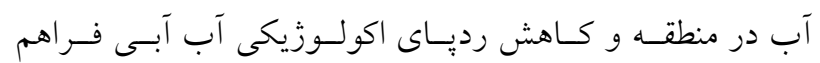
مىسازد. با توجه بـهـ بررسى تجـارت آب مجـازى در بـادام، از كـل

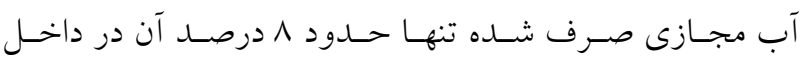

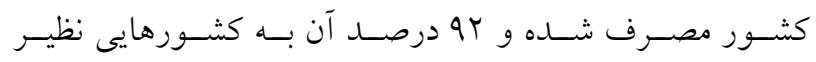

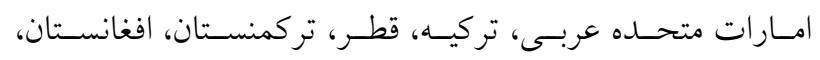

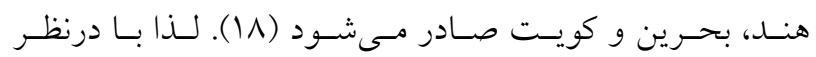

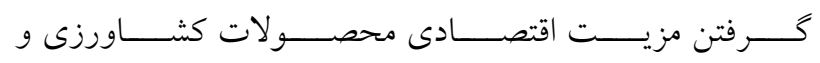

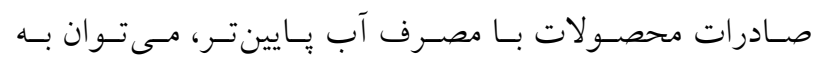
ذخيره و حفظ منابع آب سطحى و زيرزمينى كشور كمى زيادى

حجم آب مجازى آب خاكسترى در بـادام ديــم و فاريـاب

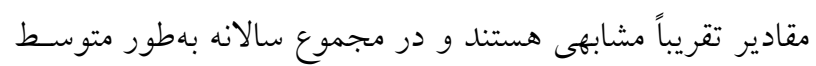
KYV

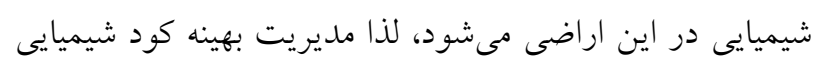

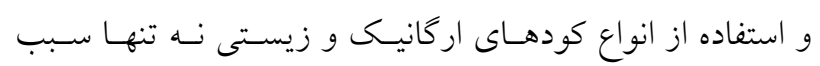

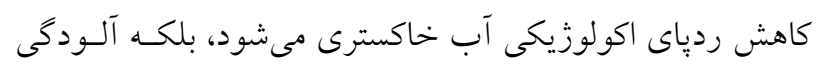

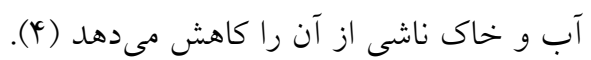

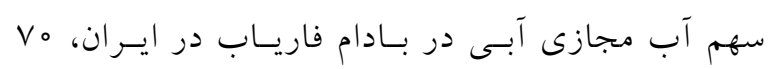

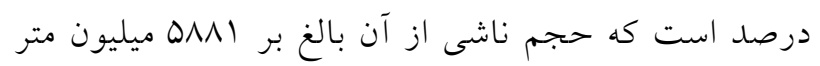

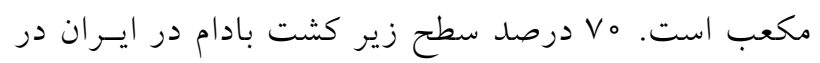

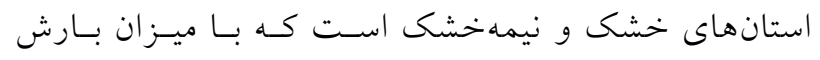

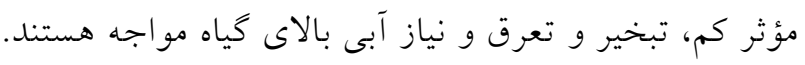

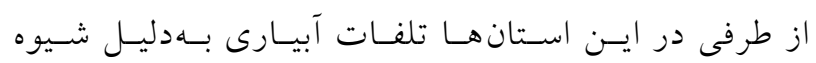

سياست هاى تشويقى باشند. در مقياس ملى، اسـتان خراسـان

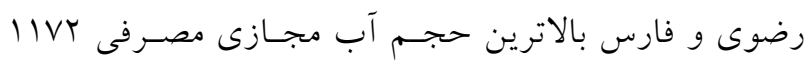

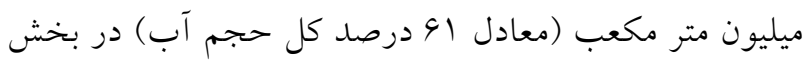

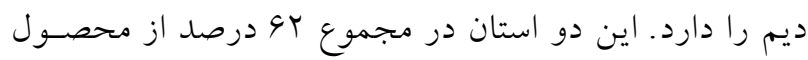

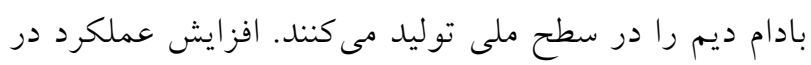

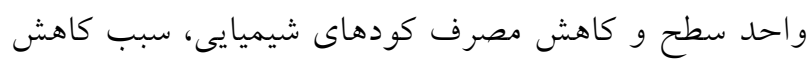

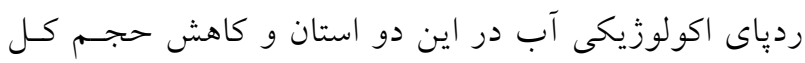
ردياى بادام ديم در سطح كشور مى شود د. متوسط حجــم آب مجـازى در بــادام فاريـاب در ايسران

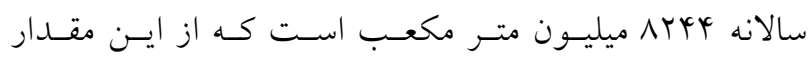

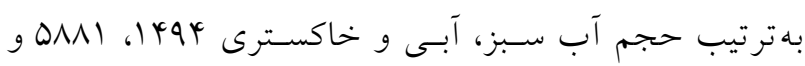

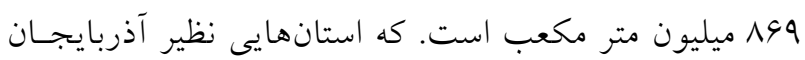

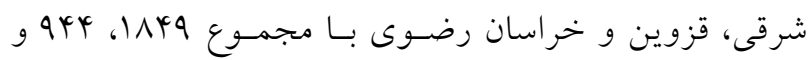

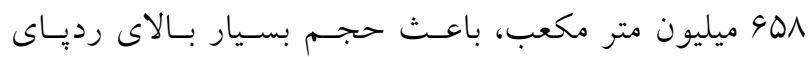

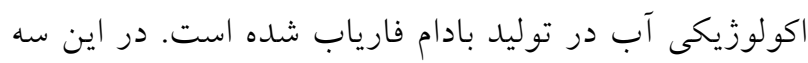

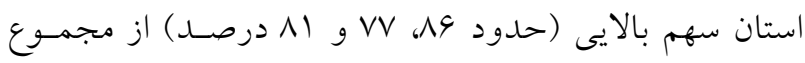

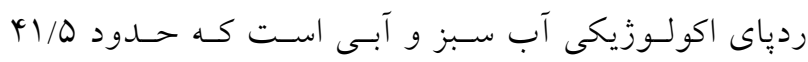

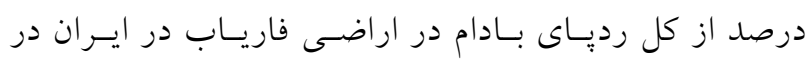

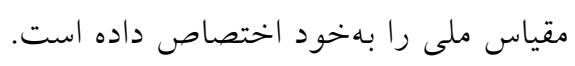

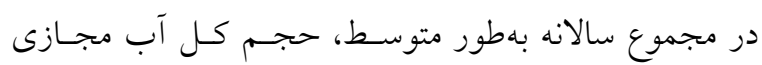

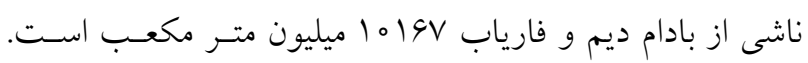

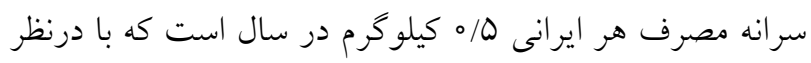

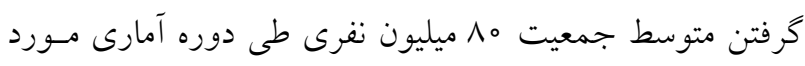

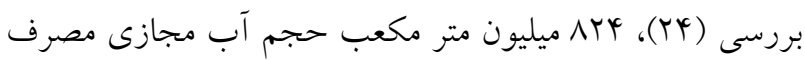

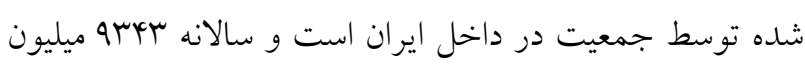
متر مكعب آب بـهــورت مجـازى بـه ديخـــ كشـورها صـادر

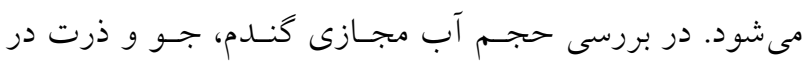

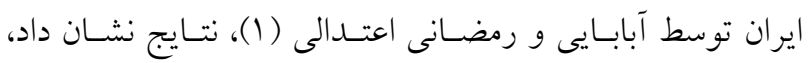

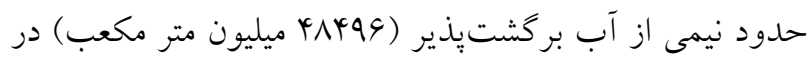

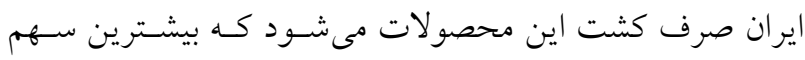

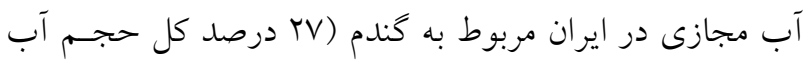

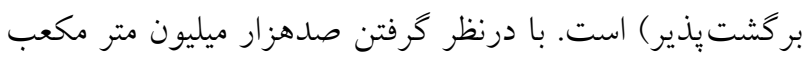


ير اكنش تقريباً منظمى برخوردار است. بخش هاى مركزى و

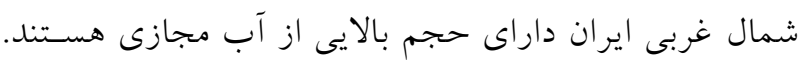

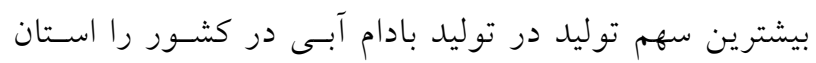

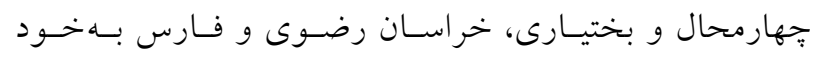

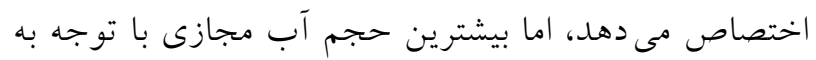

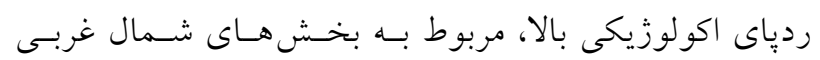
ايران است. براى بررسى تغييرات زمانى حجم آب مجازى، ميزان كل

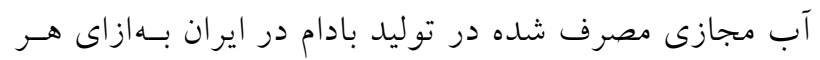

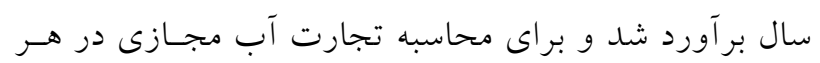

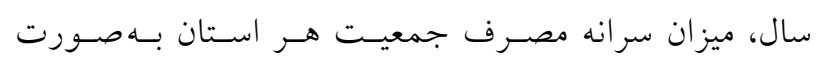

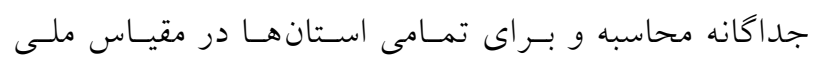

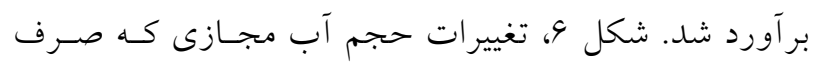

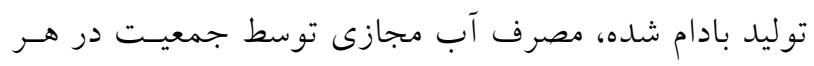

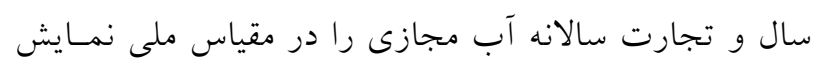
مى دهد. بر اساس نتايج، طبق افزايش جمعيت از سال IrNV

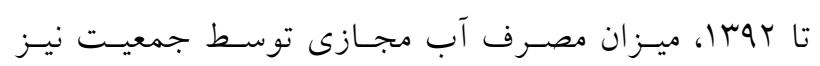

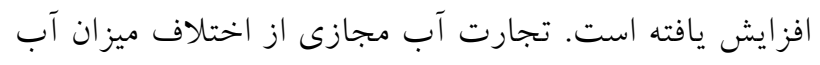

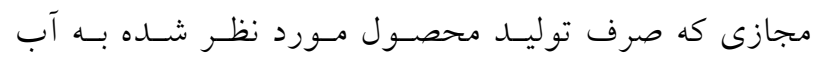
مجازى مصرف شده در داخل كشور توسط جمعيت بـر آورد

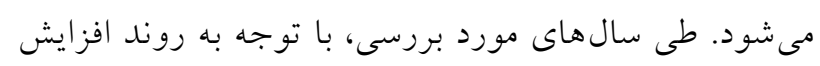

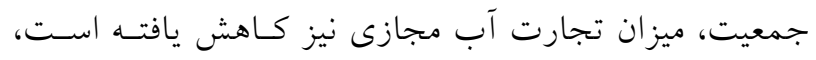
به طورى كه طى سـال هـاى

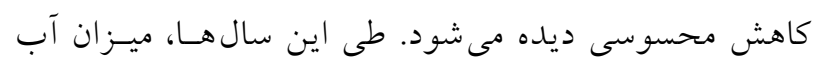

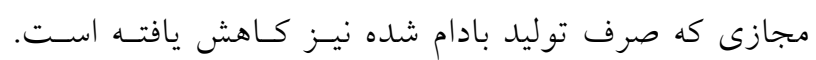

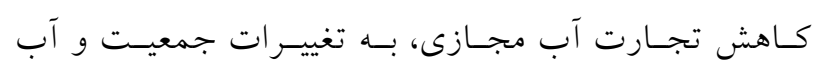

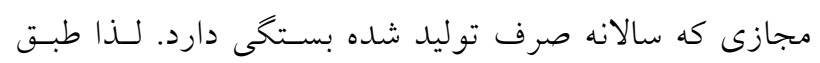
نتايج بهدست آمده در بررسى تغييرات زمانى ردياى آب آب بادام

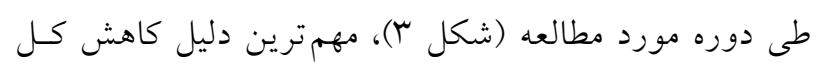

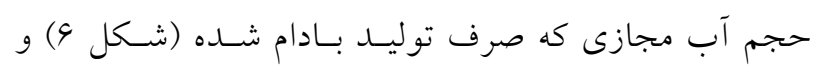
متعاقباً كاهش تجارت آب مجازى، كاهش ردياى آب در در اين

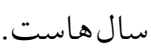

نامناسب آبيارى نيز سبب افزايش سهم رديـاى اكولـوزيكى

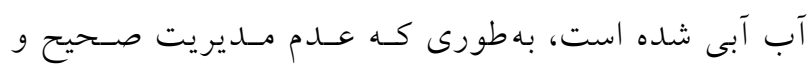

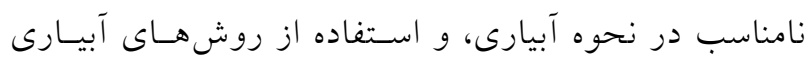

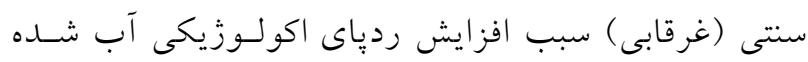

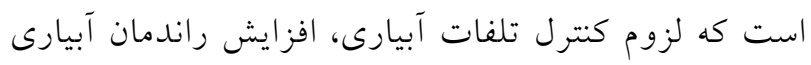

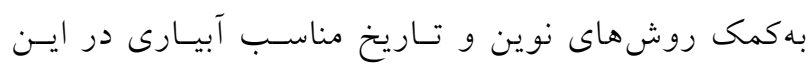

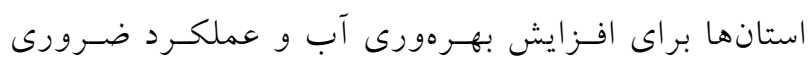

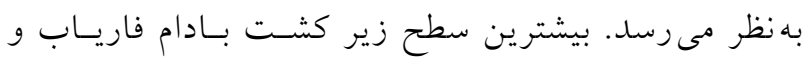

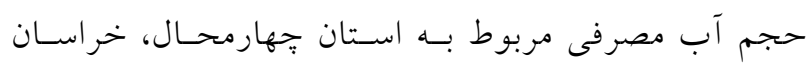

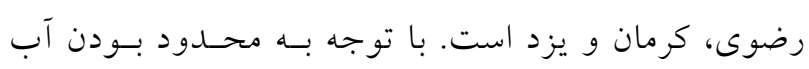

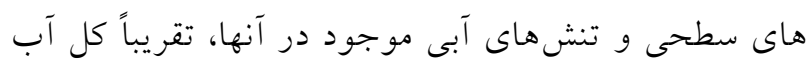

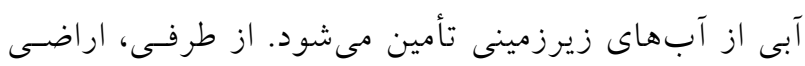

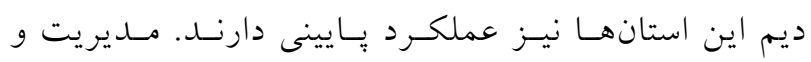

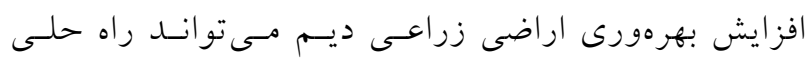

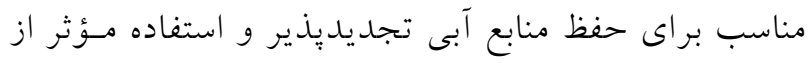
بارش در منطقه باشد.

تغييرات مكانى و زمانى حجــم آب مجــازى و تجـارت آب مجازى در ايران تغييرات مكانى حجم كل آب مجازى بر حسب ميليـون متـر

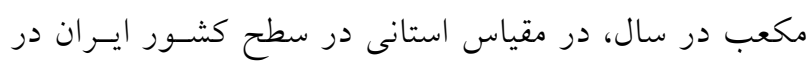

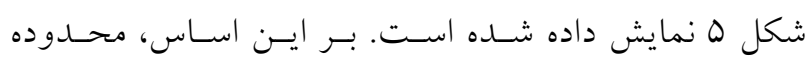
تغييرات حجم آب مجازى ناشى از توليد بادام ديم در ايسران

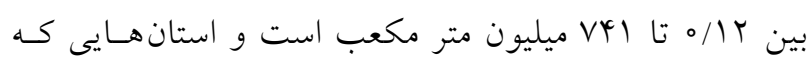

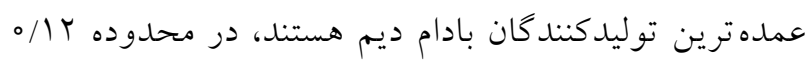

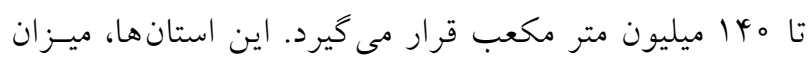

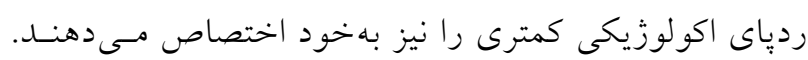

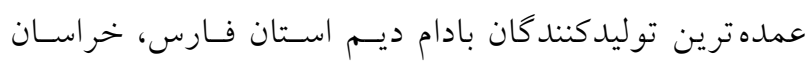

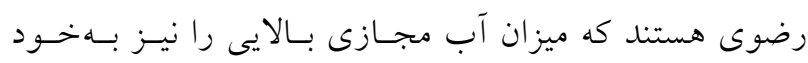

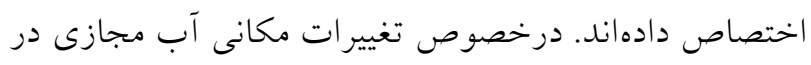

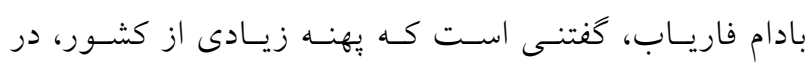

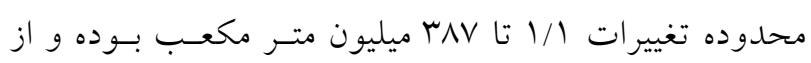



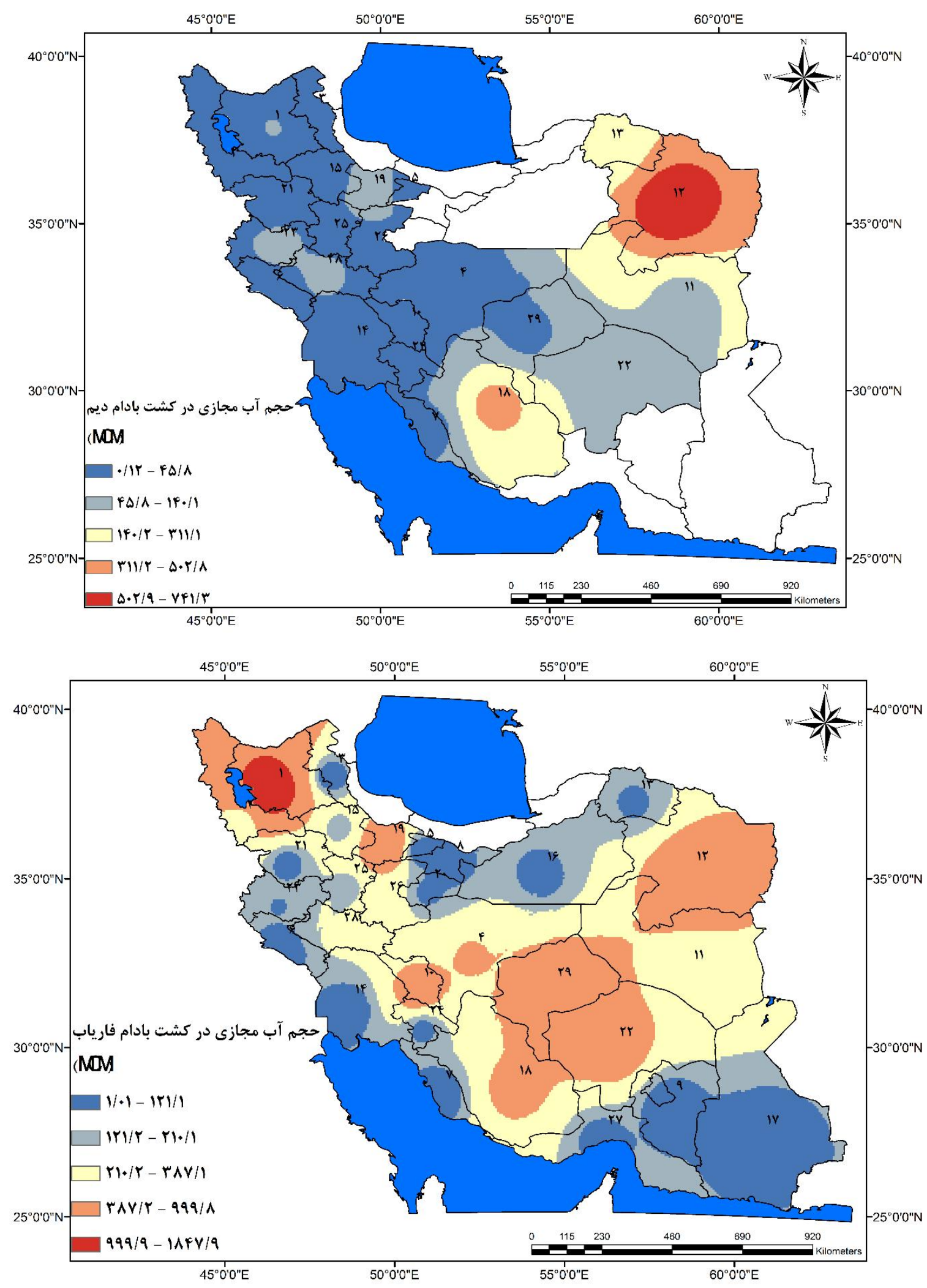

شكل ه- تغييرات مكانى حجم كل آب مجازى در محصول بادام ديم و فارياب در ايران (كد هر استان در جدول ا ارائه شده است)

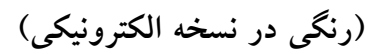




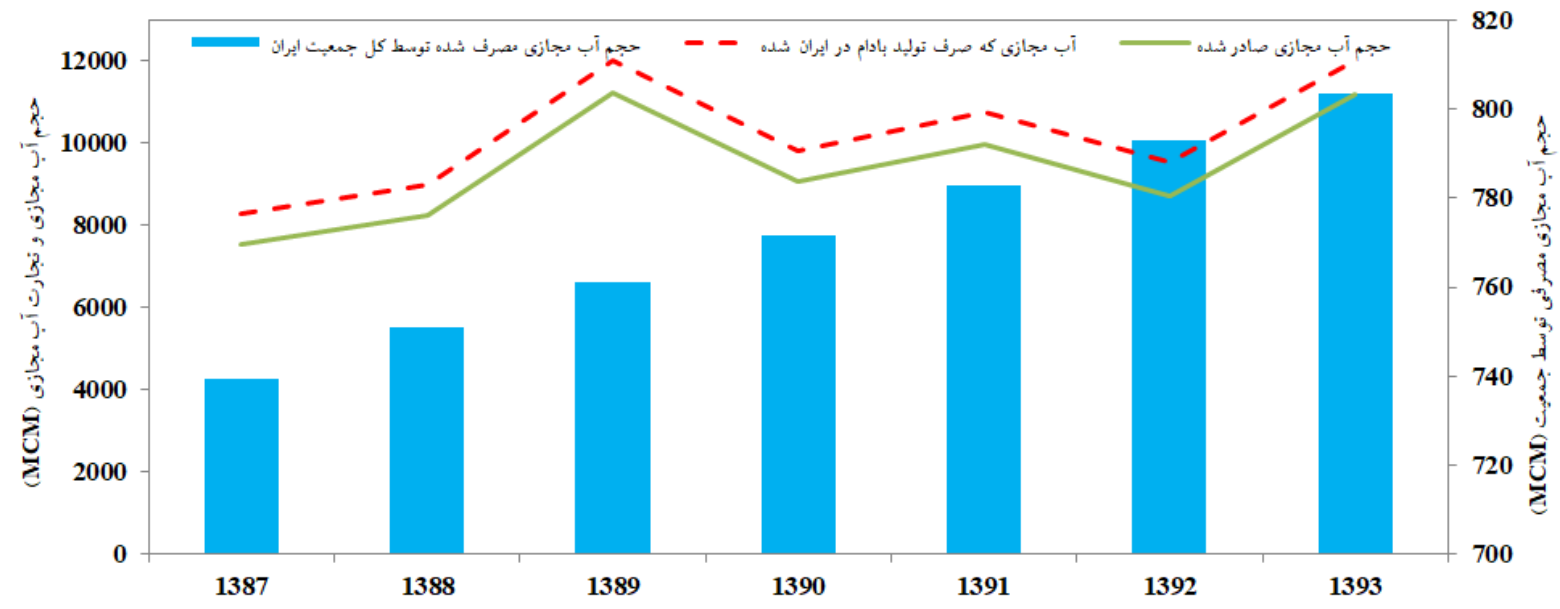

شكل צ. تغييرات زمانى حجم آب مجازى و تجارت آب مجازى در ايران (رنكى در نسخه الكترونيكى)

فارياب است. لذا توجـهـ بـهـ تبـــيل اراضسى فاريـاب در منــاطق

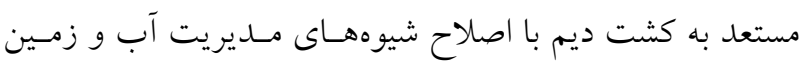
امرى ضرورى بهنظر مىرسد.

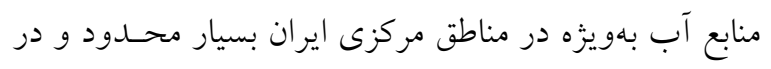

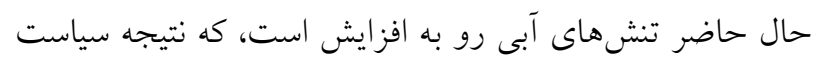
نادرست دولت در توسعه اراضى كشاورزى طى دو دهل كذشـته

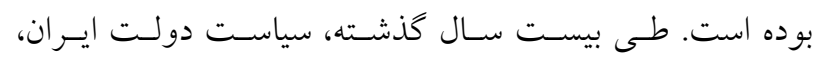

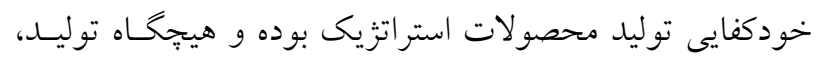

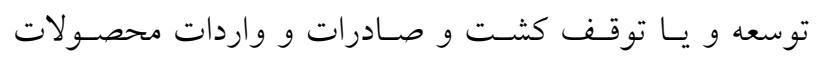

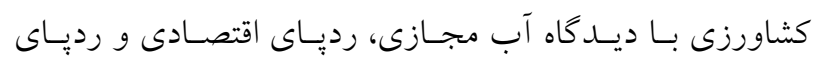

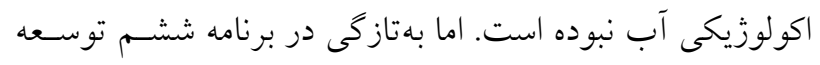

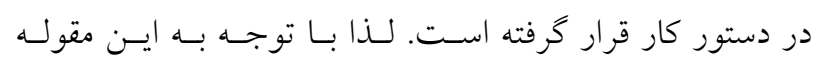

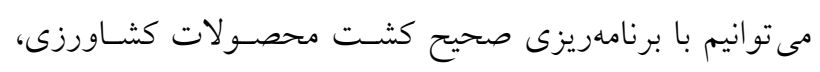
ميزان دسترسى خود را به منابع آب جهانى افزايش دهيم.

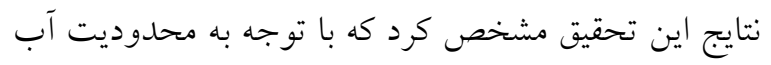

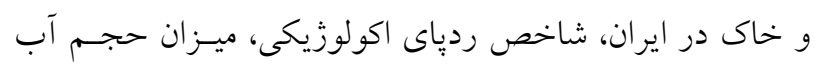

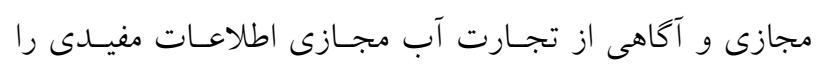
براى اولويتبندى كشت محصول در مناطق مستعد ارائه مى كند

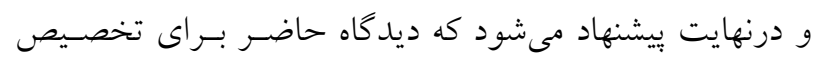

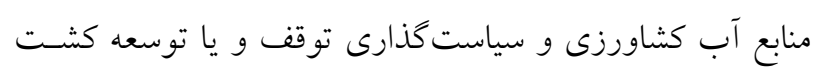
در مقياس استانى و ملى وارد شود.

\section{نتيجه گيرى}

تحقيق فوق با هدف تغييرات زمانى و مكانى ردياى اكولـوزيكى

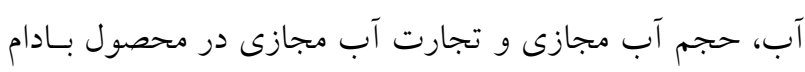

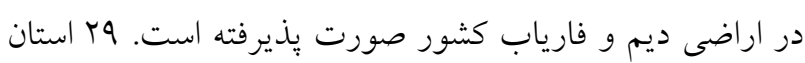

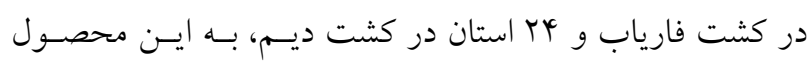
باغى مبادرت مىورزند. ايران جهـارمين توليــ كننــه بـادام در دنياست كه سالانه حجم زيادى از محصول توليد شده را رواندانس كشورهاى همسايه مى كند.

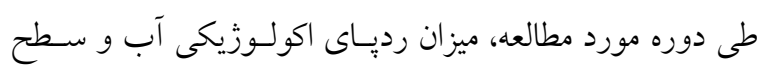

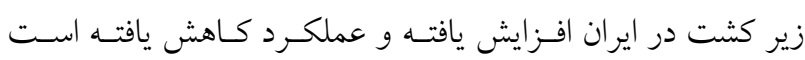

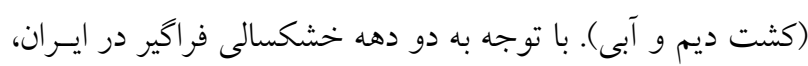

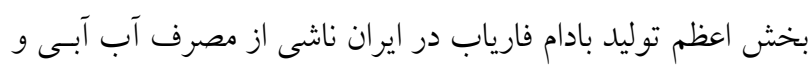

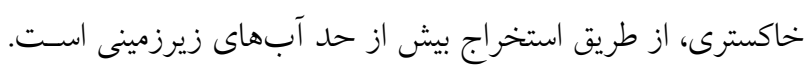

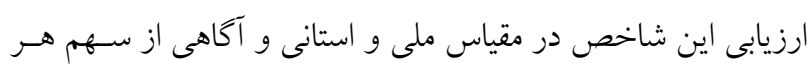

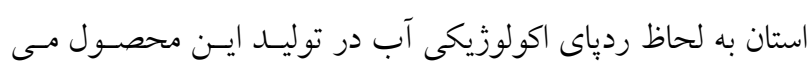

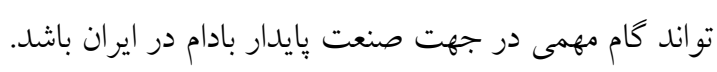

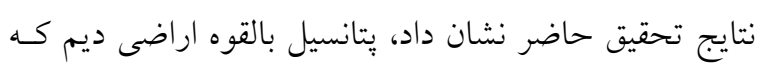

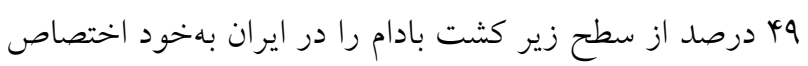

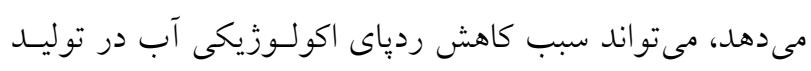

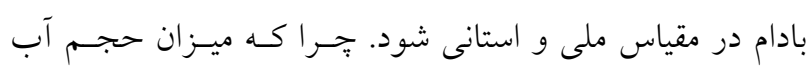

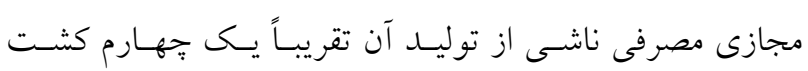


1. Ababaei, B. and H. Ramezani Etedali. 2017. Water footprint assessment of main cereals in Iran. Agricultural Water Management 179: 401-411.

2. Ababaei, B. and H. Ramezani Etedali. 2015. Estimation of water footprint parsts in national wheat production. Journal of Water and Soil 29(6): 1458-1468. (In Farsi).

3. Allan, J. A. 1997. Virtual water: A long-term solution for water short Middle Eastern economies? Paper presented at the 1997 British Assoc. Festival of Sci., University of Leeds, UK.

4. Bazrafshan, O., H. Ramezani Etedali, Z. Gerkani Nezhad Moshizi and M. Shamili. 2019a. Virtual water trade and water footprint accounting of Saffron production in Iran. Agricultural Water Management 213: 368-374.

5. Bazrafshan, O., H. Zamani, H. Ramezani Etedali and S. Dehghanpir. 2019b. Assessment of citrus water footprint components and impact of climatic and non-climatic factors on them. Scientia Horticulturae 250: $344-351$.

6. Bazrashan, O. and Z. Gerkaninezhad Moshizi. 2018. The impacts of climate variability on spatiotemporal water of tomato production in the Hormozgan. Journal of Water and Soil 32(1): 29-43. (In Farsi).

7. Chapagain, A. K., A. Y. Hoekstra, H. H. G. Savenije and R. Gautam. 2006. The water footprint of cotton consumption: An assessment of the impact of worldwide consumption of cotton products on the water resources in the cotton producing countries. Ecological Economics 60: 186-203.

8. Chouchane, H., A. Y. Hoekstra, M. S. Krol and M. M. Mekonnen. 2015. The water footprint of Tunisia from an economic perspective. Ecological Indicators 52: 311-319.

9. Fulton, J., M. Norton and F. Shilling. 2019. Water-indexed benefits and impacts of California almonds. Ecological Indicators 96: 711-717.

10. Gholamhossienpour Jafarinejad, A., A. Alizadeh and A. Neshat. 2013. Study on Ecological Water Footprint and indicators of virtual water in Agricultural Section of Kerman Province. Irrigation and Water Engineering 4(1): 8089.

11. Hoekstra, A. Y. and A. K. Chapagain. 2008. Globalization of Water: Sharing the Planets Freshwater Resources. Blakwell Publishing, Oxford, UK.

12. Hoekstra, A. Y. and P. Q. Hung. 2002. Virtual water trade: A quantification of virtual water flows between nations in relation to international crop trade. Value if the Watre Research Report Series. No. 11, UNESCO-IHE, Delft.

13. Hoekstra, A. Y., A. K. Chapagain, M. M. Aldaya and M. M. Mekonnen. 2011. The Water Footprint Assessment Manual. Earthscan, London.

14. Islamic Republic Iran Meteorological Organization, 2016. WWW.IRIMO.ir

15. Lu, Y., X. Zhang, S. Chen, L. Shao and H. Sun. 2016. Changes in water use efficiency and water footprint in grain production over the past 35 years: a case study in the North China Plain. Journal of Cleaner Production 116: 71-79.

16. MAJ 2017. Ministry of Agriculture Jihad. WWW.maj.ir.

17. Mekonnen, M. M. and A. Y. Hoekstra. 2011. The green, blue and grey water footprint of crops and derived crop products, Hydrology and Earth System Sciences 15: 1577-1600.

18. Omidi, F. and M. Homaee. 2015. Deriving crop production functions to estimate wheat virtual water and irrigation water price. Cereal Research 5(2): 131-143.

19. Pirayesh, H. R. and A. Khazaeian. 2012. Using almond (Prunus amygdalus L.) shell as a bio-waste resource in wood based composite. Composites 43: 1475-1479.

20. Rahemi, A. and A. Yadollahi. 2006. Rainfed almond orchards in Iran, ancient and new methods and the value of water harvesting techniques. In IV International Symposium on Pistachios and Almonds 30 Nov, 2006.

21. Ridoutt, B. G. and S. Pfister. 2010. A revised approach to water footprinting to make transparent the impacts of consumption and production on global freshwater scarcity. Global Environment 20: 113-120.

22. Safi, R. and S. Amirlatifi. 2015. Evaluation of sugarcane cultivation in the Khuzestan province in the context of virtual water. Water Resources Engineering 8(25): 87-96.

23. Salari, S., F. Karandish and A. Darzi-Naftchali. 2015. Spatial and temporal analyses of the wheat virtual water variations in Sistan and Blouchestan Province. Irrigation and Water Engineering 5(2): 81-94.

24. Satatistical Center of Iran, 2016. WWW.amar.org.

25. Shokoohi, A., H. Ramezani Etedali, S. Mojtabavi and V. P. Singh. 2016. Using water footprint accounting for optimizing crop patterns respecting sustainable development (case study: Qazvin plain). Iran Water Resources Research 12(3): 99-113. (In Farsi). 


\title{
Spatial and Temporal Changes of Ecological Water Footprint and Virtual Water Trade in Irrigated and Rain-fed Almond Production at Iran
}

\author{
K. Vafaei ${ }^{1}$, O. Bazrafshan ${ }^{1 \star}$ and H. Ramezanietedali ${ }^{2}$
}

(Received: September 12-2019; Accepted: December 25-2019)

\begin{abstract}
Estimating the ecological water footprint and the virtual water trade in different agricultural crops in arid and semi-arid regions can help better manage the limited water resources. This research calculated temporal and spatial ecological water footprint of rain-fed and irrigated almond production in national and provincial scale using during 2008 to 2014. The results show that annual average water footprint in rainfed almond is $9.2 \mathrm{~m}^{3} / \mathrm{kg}$, which the share of green and grey water is $72 \%$ and $28 \%$, respectively which Ilam and Kohgiloyeh \& Boyerahmad have a largest share in green water footprint with $91 \%$ and $90 \%$, respectively. In adition to, in irrigated almond, the annual average water footprint is 11.4 $\mathrm{m}^{3} / \mathrm{kg}$, which the share of green, blue and grey water is $0.19 \%, 71 \%$ and $10 \%$, respectively. Sistan \& Balouchestan, Khuzestana and Hormozgan have the highest share in blue water footprint. The total volume of water footprint of rainfed and irrigated almond production is 1923 and $8242 \mathrm{MCM}$, respectively. Also, results show that about 92 percent of the total volume virtual water (equivalent to $9343 \mathrm{MCM}$ per year) in almond production, has been exported to other countries through the virtual water trade.
\end{abstract}

Keywords: Water footprint, Rain-fed and Irrigated Almond, Provincial Level, National Level.

1. Department of Natural Resources Engineering, Faculty of Agriculture and Natural Resources, University of Hormozgan, Bandar Abbas, Iran.

2. Water Sciences and Engineering Department, Imam Khomeini International University (IKIU), Qazvin, Iran.

*: Corresponding author, Email: O.bazrafshan@hormozgan.ac.ir 